\title{
STRATEGIC REGULATORS AND THE CHOICE OF RULEMAKING PROCEDURES: THE SELECTION OF FORMAL VS. INFORMAL RULES IN REGULATING HAZARDOUS WASTE
}

\author{
JAMES T. HAMILTON* AND CHRISTOPHER H. SCHROEDER** \\ I \\ INTRODUCTION
}

\section{A. Overview}

This article examines the selection of decisionmaking procedures by regulatory agencies, using the Environmental Protection Agency ("EPA") and its implementation of the Resource Conservation and Recovery Act ("RCRA") as our source of data. It seeks to refine recent work that has explicated the role that congressional selection of agency procedures plays in the efforts of Congress to control agency policy. ${ }^{2}$

Copyright $\mathbb{C} 1994$ by Law and Contemporary Problems

* Assistant Professor of Public Policy, Economics, and Political Science, Duke University.

** Professor of Law, Duke University School of Law.

We would like to thank Valeria Balfour, Justin Hoagland, John Lange, and Jennifer Vogdes for their research assistance and the Duke Law School Olin Program in Law and Economics for financial support. Participants at the Law and Contemporary Problems conference and Terry Sanford Institute seminar provided helpful comments, especially Donald Elliott, Daniel Farber, Jeffrey Lubbers, and James Miller.

1. 42 U.S.C. $\S \S 6901-6992$ (1988).

2. Mathew D. McCubbins, Roger G. Noll \& Barry Weingast, Administrative Procedures as Instruments of Political Control, 3 J.L. ECON. \& ORG. 243 (1987) [hereinafter McNollgast, Administrative Procedures]. Although BlueBook style calls for the use of "et al." when more than two authors are listed, we have listed all three authors' names here because of the peculiar nature of their writings. The three authors listed often publish jointly under the pseudonym "McNollgast." Thus, all references to McNollgast also represent McCubbins, Noll, and Weingast. Mathew D. McCubbins, Roger G. Noll \& Barry R. Weingast, Structure and Process, Politics and Policy: Administrative Arrangements and the Political Control of Agencies, 75 VA. L. REV. 431 (1989) [hereinafter McNollgast, Structure and Process]; Mathew D. McCubbins, Roger G. Noll \& Barry R. Weingast, Positive Canons: The Role of Legislative Bargains in Statutory Interpretation, 80 GEO. L.J. 705 (1992); see also Murray J. Horn \& Kenneth A. Shepsle, Commentary on "Administrative Arrangements and the Political Control of Agencies": Administrative Process and Organizational Form as Legislative Responses to Agency Costs, 75 VA. L. REV. 499 (1989); Jonathan R. Macey, Organizational Design and the Political Control of Administrative Agencies, 8 J.L. ECON. \& ORG. 93 (1992); Murray J. Horn, The Political Economy of Public Administration (1988) (unpublished Ph.D. dissertation, Harvard University). 
What unites this effort with that of McNollgast and others is its treatment of procedure as endogenous to the policy process itself. Viewing procedure this way implies that the issue of what procedural instruments policy actors choose to employ cannot be satisfactorily analyzed solely as an autonomous issue, for example, by reference simply to such relatively policy-neutral ideas as due process. The McNollgast literature has concentrated on congressional choices of procedures, exploring how Congress selects among procedural instruments in order to advance its policy objectives.

In particular, procedural instruments constitute one means by which Congress seeks to increase agency fidelity to the policy preferences of members of Congress. In other words, Congress seeks to reduce slack in agency decisionmaking that the agency can then exploit to pursue its own objectives. In general, Congress accomplishes this goal through procedures that produce political operating conditions for the agency that mirror the political environment in the Congress that produced the law, that stack the deck in favor of the enacting coalition, and that embody autopilot features enabling and motivating the agency to change policies as the policy preferences of the enacting coalition change. ${ }^{3}$

These and other investigations of Congress's capacity to exercise ex ante control over agency policy through devices other than the substantive instructions of the statutes themselves have contributed enormously to a more realistic understanding of the Congress-agency relationship. However, it is by no means clear how successful these ex ante controls are. Even after Congress has dictated certain procedures, agencies retain considerable discretion to make selections among procedural options-a degree of discretion that has been insufficiently appreciated in the developing literature on endogenous procedural selection by Congress. ${ }^{4}$ This article explores the endogeneity of procedure from the agency's perspective.

\section{B. The Congress-Agency Relationship}

In this section, we locate our study of the Congress-agency relationship within a larger context of public law scholarship. The relationship between Congress and agencies has been a major concern since the advent of the New Deal and has been the subject of work undertaken by economists and economically minded political scientists, where that relationship has become a significant part of the development of Positive Political Theory ("PPT").

These studies provide increasingly sophisticated treatments of the principalagent problem posed by congressional delegation of rulemaking responsibilities to administrative agencies. The literature can be summarized as an alternating

3. McNollgast, Structure and Process, supra note 2.

4. But see John A. Ferejohn, The Structure of Agency Decision Processes, in Congress: STRUCture AND POLICY (Mathew D. McCubbins ed., 1987); Terry M. Moe, An Assessment of the Positive Theory of "Congressional Dominance," 12 LEGAL STUD. Q. 475 (1987). 
series of hypotheses and counter-hypotheses: first, one suggesting that Congress controls, or dominates, agency decisionmaking, then a correcting or qualifying hypothesis showing that congressional domination is significantly incomplete. Each time a "congressional dominance" theory is advanced, a further look at actual agency and congressional practices stresses that significant slack still remains in the relationship, leaving the agency with considerable freedom to choose action neither dictated nor desired by the Congress. This slack produces an "agency discretion" hypothesis that emphasizes the agency's ability to deviate from congressional dictates or desires.

Early on, congressional dominance theory rested on the conviction that Congress established substantive policy with sufficient precision so that administering agencies were left only with the tasks of completing necessary details or applying general pronouncements to specific situations via noncontroversial methods of application. ${ }^{5}$ This hypothesis-that agencies were little more than transmission belts between Congress and the regulated public-collapsed in the face of general statutory delegations, such as the one empowering the FCC to approve broadcast licenses in accordance with its understanding of the "public interest, convenience and necessity." In that and other cases, Congress did not expressly resolve all policy issues before it enacted a statute; often it left that task to the agency. Thus, within broad limits, agencies appeared to be free to do largely as they chose.

The next congressional dominance hypothesis contended that such broad public interest delegations did not actually grant agencies the unfettered discretion that might at first be supposed. Instead, agencies were constrained by the need to apply some neutral methodology for determining what the public interest required, whether the methodology was the economist's search for efficient regulatory solutions to problems of market failure or some other set of professional norms, such as those of medicine or engineering. ${ }^{6}$

In its time, this hypothesis was questioned by a series of studies of actual bureaucratic performance that demonstrated that agency decisions could not routinely be squared with such methodologies, either because those methodologies were themselves indeterminate or because bureaucratic decisions were inconsistent with the actions suggested by them. ${ }^{7}$ Once again, agencies appeared largely unconstrained and free to pursue their own policy preferences.

Skepticism that a noncontroversial public interest theory of agency action could be found produced a body of scholarship advancing various models of agency discretion. Most notable among these were models of agency capture, which asserted that agencies were highly prone to control by regulated sectors

5. See Cynthia Farina, Statutory Interpretation and the Balance of Power in the Administrative State, 89 Colum. L. REV. 452 (1989); Richard B. Stewart, The Reformation of American Administrative Law, 88 HARV. L. REV. 1669 (1975).

6. Stewart, supra note 5 .

7. Id. 
of the economy. ${ }^{8}$ In this view, giving agencies discretion resulted in regulatory policy systematically favoring concentrated interests over dispersed consumer and citizen interests.

Whether or not capture theory was embraced, however, the consensus in public law scholarship throughout the 1970 s and into the early 1980s was that Congress had largely abandoned efforts to control agency outcomes. Proceeding from that premise, scholarship developed in several directions. Some scholars sought explanations for why congressional majorities would consign important social and economic interests to an agency-administered policy lottery by delving into the electoral advantages of such behavior. ${ }^{9}$ Others examined positive and normative theories of judicial response, including a revived nondelegation doctrine $^{10}$ and an "interest-representation" model of administrative law, in which agencies were treated as miniature congresses, hearing from competing interests before reaching a decision. ${ }^{11}$ Still others studied whether or not presidential controls on agency action might provide the link between the popular will and the agency thought essential to legitimate an agency's exercise of power within a democratic polity. ${ }^{12}$

At this time of competing theories, the development of a new congressional dominance hypothesis proceeded along two paths. First, scholars noted that the alleged tendency of Congress to avoid making policy choices was not uniform. In fact, in recent decades, Congress has written increasingly detailed statutes in a number of controversial fields, most notably those affecting health, safety, and the environment. Second, analysts came to recognize that writing substantively detailed statutes was not the only way Congress attempted to maintain control over agency actions. Even when statutory mandates were exceedingly general, committee oversight and investigations, coupled with threats of drafting new legislation, provided leverage over agencies to which bureau chiefs seemed to be responsive. Such ex post supervision of agency behavior resembles the monitoring behavior of principals that is one of the standard responses to the problem of slack in private principal-agent relationships. In these two ways, new congressional dominance hypotheses emerged in studies of the Congress-agency relationship. ${ }^{13}$

These newer hypotheses of congressional dominance had to take into account the unique obstacles that monitoring faces in the political setting that are not present in the private environment. Unlike private principals, majorities that enact laws are coalitions, composed of individual members with distinct and

8. John S. Wiley, Jr., A Capture Theory of Antitrust Federalism, 99 HARv. L. REv. 713 (1986).

9. Peter H. Aranson et al., $A$ Theory of Legislative Delegation, 68 CORNELL L. REV. 1 (1982).

10. See id.

11. Stewart, supra note 5 .

12. Jerry Mashaw, Prodelegation: Why Administrators Should Make Political Decisions, 5 J.L. ECON. \& ORG. 81 (1985).

13. See, e.g., Moe, supra note 4; Barry R. Weingast \& Mark J. Moran, Bureaucratic Discretion or Congressional Control? Regulatory Policymaking by the Federal Trade Commission, 91 J. POL. ECON. 765 (1983). 
potentially divergent interests. If an agency implements a policy other than that desired by the enacting coalition, it may be impossible for the coalition to restore its preference, because the agency policy may be preferred by a new coalition resistant to the restoration. This problem of bureaucratic drift is not due to the costs ôf monitoring; it can arise even when Congress has perfect information about subsequent agency decisions. ${ }^{14}$

A second difficulty arises because of the president's veto power: if deviations from congressionally preferred policy are preferred by a president prepared to veto attempts at correction, the changes can be impossible to correct even if the majority coalition stays intact. In such cases, a two-thirds coalition in both houses of Congress is required to make the change. In these two ways, freedom from congressional domination reemerged in our understanding of the Congressagency relationship, this time as a result of constitutional rules structuring the formal relationships between Congress, the president, and the agency.

In the most recent stage in the study of the Congress-agency relationship, some congressional dominance scholars acknowledge these theoretical reasons for slack in the relationship but continue to question "whether and to what extent ... shirking occur[s] in reality. Theoretically, there are several reasons to believe that agencies do not stray far from the range of policies acceptable to the supporting political coalition of the statutory policy."15 Prominent among those reasons has been the thesis that Congress selects agency procedures and other structures of decisionmaking as ex ante devices to control agency policymaking. ${ }^{16}$

Our inquiry can be considered an agency discretion counterpoint to the McNollgast congressional dominance hypothesis. We argue that agencies retain considerable freedom to select procedures under which to operate, in ways that can defeat ex ante attempts at control. This freedom enables agencies themselves to treat procedure strategically as one endogenous component of the overall process of formulating substantive policy. To explore agency selection of procedural instruments in operation, we study how the EPA utilizes available slack in the procedural selection process under RCRA.

14. See McNollgast, Structure and Process, supra note 2.

15. Roger Noll, Economic Perspectives on the Politics of Regulation, 2 HANDBOOK INDUS. ORG. 1253-87 (1989).

16. A number of different bills have been studied to document the claim that "legislators see the choice of administrative structures and processes as important in assuring that agencies produce policy outcomes that legislators deem satisfactory," and that they view procedure as "one means of guiding agencies to make decisions that are consistent with the preferences of the [winning] coalition ..., but without requiring the members of that coalition to monitor, or even be aware of, the nature of the agency's actions." McNollgast, Structure and Process, supra note 2, at 432 . These include the Clean Air Act Amendments of 1977,42 U.S.C. $\$ \S 7401,7403,7405,7426$ (1988), the Occupational Safety and Health Act of 1970, 29 U.S.C. $\$ \S 651-678$ (1988), the Consumer Product Safety Act of 1970, 15 U.S.C. $\$ 2057$ (1988), and the National Environmental Policy Act of 1969, 42 U.S.C. 4332 (1988). In each case, procedural requirements for agency action can be seen as promoting interests of the enacting coalition, including the president, by embodying "an ex ante agreement among legislators and the President that limits the ability of each to engage in ex post opportunistic behavior." McNollgast, Structure and Process, supra note 2 , at 432 . 


\section{Binding Agencies with Procedural Constraints}

Procedural constraints on agency decisionmaking have been thought to be remedies to the problem of agency noncompliance with substantive policy choices, and to be an improvement on reliance on ex post monitoring alone. For example, McNollgast writes that "the potential for agency deviations from intended policies that are difficult for politicians to punish or correct leads them to devise institutions that limit an agency's ability to deviate."17 The literature on procedural constraints has failed, however, to explain why we should not expect the same tendency to deviate to arise when agencies are faced with procedural instructions as we do when they are faced with substantive directives. Why, in other words, do procedural instructions bind more effectively than policy instructions?

One possible, but ultimately unpersuasive, explanation is that agencies view procedural rules as occupying a policy sphere that is independent from substantive policy, and thus somewhat less susceptible to agency manipulation than substantive instructions. This argument reflects a "legal idealist" conception of procedure that treats procedure as relatively policy-neutral, with decisions about what procedures to follow being made relatively independently of the substantive policy the procedures implement. Legal idealism may still be the dominant view of procedures among lawyers and legal academics generally. ${ }^{18}$

It is true that one way of controlling agency shirking is to delegate tasks to professionals who will be constrained by their own professional norms. ${ }^{19}$ The legal idealist argument for the efficacy of procedural constraints rests, however, on the assumption that agency lawyers are as subject to legal idealism as the profession as a whole, and this assumption is questionable. A central insight of the McNollgast literature is that legislators are aware of the policy relevance of procedural choices and use procedure to advance policy objectives. Agency personnel are at least as attuned to the dispositions and beliefs of legislators, whose actions so profoundly influence their agency's options, as they are to their own professional norms. There is no compelling reason to believe that even agency lawyers would be unaware of the endogeneity of procedure.

Furthermore, legal idealist norms are quite weak in informing many of the most significant procedural choices faced by administrative agencies, so that even if legal idealist influence was actually quite compelling among agency lawyers, that influence would not extend to the relevant agency decisions. Provisions of the Administrative Procedure Act ("APA"), ${ }^{20}$ the necessity of producing an adequate administrative record for purposes of judicial review, and general due

17. McNollgast, Structure and Process, supra note 2, at 431, 443.

18. Jerry L. Mashaw, Improving the Environment of Agency Rulemaking: An Essay on Management, Games, and Accountability, 57 LAW \& CONTEMP. PROBS. 185 (Spring 1994).

19. D. Roderick Kiewiet \& Matthew D. MCCubbins, The Logic of Delegation (1991); Moe, supra note 4.

20. 5 U.S.C. $\$ \S 701-706(1988)$. 
process considerations have all been invoked from time to time in judicial decisions to justify imposing specific procedural requirements on agencies, ostensibly on policy-neutral, idealist grounds. This body of case law, however, addresses procedural details within basic procedural instruments such as noticeand-comment rulemaking or adjudication. There is very little developed and authoritative doctrine concerning the prior choice by the agency of which procedural instrument to employ in the first place-whether to proceed by rule or by adjudication, for example, or by guidance document or notice-andcomment rulemaking. Accordingly, few legal idealist norms exist to guide the agency's choice among procedural instruments, and, as we show in the case of RCRA below, agencies retain considerable discretion to choose among those instruments on policy-relevant grounds. ${ }^{21}$

A second explanation for the greater effectiveness of procedural constraints might rest on the possibility that ex post means for monitoring procedural compliance are more effective than they are for monitoring substantive compliance, so that agency fidelity to congressional procedural preferences is more likely. Indeed, congressional committees do hold oversight hearings that delve into the procedures through which agencies have reached decisions. Most notable in recent years have been hearings into the roles of the Office of Management and Budget ("OMB") and of the Competitiveness Council in influencing agency outcomes. Again, however, there is no reason to suppose that monitoring of procedure is any more effective than ex post monitoring of substantive policy-and it was in response to the perceived inadequacies of the latter type of ex post monitoring that procedural constraints were hypothesized as a corrective. ${ }^{22}$

21. Many of these decisions were rendered during the development of "hard look" review in the 1970s. For a review of the prominent cases, see WALTER GELLHORN ET AL., ADMINISTRATIVE LAW: CASES AND MATERIALS 475-86 (8th ed. 1987). Much of the judicial development of procedural requirements beyond the APA itself was halted by the Supreme Court's decision Vermont Yankee Nuclear Power Corp. v. NRDC, 435 U.S. 519 (1978). See infra text accompanying notes 23-25.

22. "Fire alarm" monitoring by interest groups that supported the successful enacting coalition is a second monitoring device. In the McNollgast analysis, procedural constraints on agency action reduce agency shirking in part by providing early access to agency deliberations for private interest groups. This enables those groups to sound a fire alarm if the agency deviates from their own interests, possibly triggering oversight activity by the congressional coalition that enacted the legislation. McNollgast, Administrative Procedure, supra note 2, at 259-60.

Fire alarm monitoring can lead to agency changes in procedural mechanisms. In 1989, the EPA proposed to revise the criteria for determining a "wetlands" for purposes of Clean Water Act jurisdiction and its requirement that private parties obtain a $\$ 404$ permit before dredging or filling a wetlands. The revision took the form of updating a technical manual written by the EPA to assist its field offices and those of the Army Corps of Engineers in making such determinations, and was initially done without public participation. Announcement of the EPA's intentions prompted considerable public outcry from property owners and, in response to this outcry and to expressions of congressional concerns that the revisions lacked adequate input from affected parties, the EPA pulled back on its plans in order to initiate a round of public hearings across the country.

Sounding the fire alarm on procedure can be effective in this way. However, the relevant question is whether there is reason to believe it to be more effective in monitoring procedure than in monitoring substance, where it is also conceded to be occasionally effective, but not enough to satisfy the Congress, which has developed procedural constraints to increase agency responsiveness to congressional 
Finally, it might be that the courts can be relied upon to enforce the institutional and procedural structure selected by the Congress. Insofar as the procedural structure has been precisely defined by Congress, courts do appear to perform this function. Just as Chevron v. Natural Resources Defense Council, Inc. ${ }^{23}$ indicates that courts ought to enforce substantive congressional policy choices where those have been unequivocally made, they should, and do, enforce specific congressional procedural choices where those have been clearly made. One aspect of our thesis, however, is that there is considerably more room for agency selection of procedures than has yet been thoroughly explored in the literature. This contention raises a question with respect to the courts, namely whether they are employing procedural rulings for substantive policy-based reasons. In other words, do the courts, as well as the legislature and the agency, treat procedure as endogenous?

The policy basis for significant procedural rulings in the 1960s and 1970s has been well recognized in the legal literature. ${ }^{24}$ It is generally argued that the Vermont Yankee decision ${ }^{25}$ terminated or radically diminished such policy-based judicial impositions on agencies. At most, however, Vermont Yankee prohibits federal courts from imposing additional procedural requirements beyond those announced by Congress, whether through the generally applicable APA or the agency's enabling legislation. We have already suggested that a major source of agency flexibility comes not in the addition or subtraction of procedural details to a structure ordained by Congress, but rather from the initial selection among procedural structures or instruments themselves. If that is so, this re-opens the possibility of courts encroaching on such agency flexibility for policy-based reasoning in ways not clearly prohibited by Vermont Yankee. We are not prepared to undertake an examination of this possibility at this time, but we do note it as an object worthy of future study. ${ }^{26}$

The hypothesis that procedures constrain bureaucratic policy drift relies upon the premise that such drift can be kept within tolerable bounds. In this section, we have raised some theoretical reasons to doubt whether Congress can easily control procedural drift to a significantly greater extent than it can policy drift. In the next section, a closer examination of how agencies perform their policy roles reveals that there are, in fact, several important stages in the making and implementing of agency rules that provide the opportunity for such drift.

preferences. And once again, we can think of few reasons to suppose that the answer to this question is affirmative.

23. 467 U.S. 837 (1984).

24. Stewart, supra note 5.

25. Vermont Yankee Nuclear Power Corp. v. Natural Resources Defense Council, Inc., 435 U.S. 519 (1978).

26. For applications of the methods of positive political theory to courts, see William N. Eskridge, Jr. \& John Ferejohn, The Article I, Section 7 Game, 80 GEO. L.J. 523 (1992); Rafael Gely \& Pablo T. Spiller, A Rational Choice Theory of Supreme Court Statutory Decisions with Applications to the State Farm and Grove City Cases, 6 J.L. EcoN. \& ORG. 263 (1990); Pablo T. Spiller \& Matthew L. Spitzer, Judicial Choice of Legal Doctrines, 8 J.L. ECON. \& ORG. 8 (1992). 


\section{The Resource Conservation and Recovery Act}

1. Opportunities for Agency Discretion in Translating Congressional Policy into Influences on Private Behavior. In 1976, Congress enacted RCRA, establishing the basic regulatory structure still in place today. ${ }^{27}$ Congress has, however, subsequently revised RCRA in several ways significant to the present study. Among other things, RCRA empowers the EPA to issue standards for generators and transporters of hazardous wastes and for operators of treatment, storage, and disposal ("TSD") facilities, and it establishes a permit system to enforce these standards. We use the EPA's implementation of RCRA's permitting system as a laboratory to study the role of procedure in constraining agency action, and also to study the continuing ability of the agency to exercise its own discretion in choosing implementation procedures. RCRA presents a particularly interesting study for our thesis-that agencies retain considerable discretion to choose among procedural options-because the statute is often cited as an instance of Congress manifesting its policy preferences in considerable detail through both substantive language and procedural constraint.

Procedural and structural directions written into statutes such as RCRA perform two major functions for Congress: (1) through disclosure and participation requirements, they enable the constituencies who supported the legislation to monitor agency behavior and to signal Congress as problems arise, and (2) through analytical, factual, and participatory requirements, they give leverage to those same constituencies in the agency decisionmaking process, thereby creating institutional conditions that channel the agency toward policies compatible with the enacting coalition's preferences, even if those preferences were not precisely known at the time of enactment. We refer to these two functions as the monitoring and channeling functions, respectively. To assess the efficacy of procedural constraints in performing these functions, we need to examine the actual workings of agency rulemaking in some further detail.

First, procedures cannot channel if the agency does not use them. Inaction has always been a significant tool in agency efforts to defect from congressional policy direction. The literature expanding on the McNollgast thesis frequently assumes that the agency will activate whatever procedural mechanism Congress has codified, but this is by no means necessarily so.

Congressional coalitions interested in agency action have been aware of this problem for some time, and over the past two decades have developed a number of action-forcing instruments. These include writing statutes in terms of nondiscretionary duties, drafting deadlines by which time the agency must have acted, and employing statutory "hammers," which place certain regulatory consequences immediately into effect unless the agency has written a rule or taken some other specific action by a certain deadline. Nondiscretionary duties

27. Robert V. Percival et. Al., Environmental Regulation, Law, Science and Policy 214-26 (1992). 
and deadlines, however, have had only limited effectiveness, while hammers have limited utility, insofar as they require Congress to write specific substantive provisions, which is the very task that delegation to an agency is intended to obviate. ${ }^{28}$

Second, even when the agency determines to act, it retains more discretion than might be expected. Translating a statute like RCRA into tangible policy that influences private behavior entails three distinct stages. At each stage, the agency has considerable discretion to make choices that result in deviation from congressional policy.

The first stage is rule enunciation. Here the agency interprets and amplifies a statutory provision to articulate a regulatory rule. Paradigmatically, this occurs through some kind of agency rulemaking proceeding, involving one or more public notices of the proposed rule, a comment period, perhaps a revision of the proposal followed by more comment, intensive and extensive review and analysis inside and outside of the agency, and eventually the publication of the rule in the Federal Register.

The precise rulemaking procedures are subject to individualized specification by Congress, and it is in these specifications that McNollgast sees opportunities for Congress to empower private interests to monitor agency action, and also to mirror the political environment and stack the procedural deck by, for instance, requiring rules to meet the substantial evidence standard of judicial review rather than the arbitrary and capricious standard, or by requiring the agency to resolve technical issues where expertise and knowledge reside disproportionately under the control of one party or another.

In the McNollgast story, agencies enunciate rules by deploying the statutorily crafted procedures. In reality, however, agencies have more options. For one, they can deploy the statute's procedures to enunciate a rule that is, in important respects, still incomplete. For example, RCRA contained an April 1978 deadline for the promulgation of Subtitle C (hazardous waste disposal) regulations. The rule the EPA eventually issued exempted several significant categories of waste disposal, including burning of hazardous waste for energy recovery, on the ground that the EPA had insufficient information to issue rules. As another example, the EPA's RCRA rules quite often leave open complete technical specification of topics like engineering standards for groundwater monitoring, or the security requirements for post-closure care of a TSD facility. Subsequently, these can be filled in through intra-agency memoranda, guidance manuals, policy statements, or references to third-party documents-none of which are typically issued via the statutory procedures for rulemaking. Opting for these procedures means opting for procedural structures in which the monitoring and channeling functions Congress has built into the statute are not operative.

28. For a review of the use of these devices, see Sidney A. Shapiro \& Robert L. Glicksman, Congress, the Supreme Court, and the Quiet Revolution in Administrative Law, 1988 DUKE. L.J. 819. 
Regardless of what procedures the agency chooses to use to enunciate a rule, significant additional steps in the policy implementation process remain to be completed, each presenting new opportunities for strategic agency behavior. The second stage is rule application. RCRA requires that rules for TSD facilities be translated into a permit for each regulated facility. Under the RCRA system of federal-state sharing of authority, these permits are often largely written by state agencies, although EPA regional offices retain responsibility for writing certain provisions established by the 1984 Hazardous and Solid Waste Amendments Act (the "HSWA") until states obtain approval to do so. Wherever the permits are written, the system of permit writing provides opportunity for individualized negotiation of at least some permit terms. Once again, the statutory procedures for monitoring and channeling of the rule enunciation phase do not generally apply to this stage of the implementation process.

In the third and final stage, the agency engages in rule enforcement-where, once again, significant opportunities for discretionary decisionmaking exist. If an objectionable pattern of rule enforcement becomes sufficiently noticeable, private interests can sound the alarm, as occurred in the case of both Superfund and RCRA in the early $1980 \mathrm{~s}^{29}$ In the case of RCRA, industrial interests have from time to time been among those urging a more consistent enforcement policy because, as Chemical Week once noted, "[i]n a highly competitive industry, companies cannot afford to spend their resources on environmental protection, however well conceived the rules, unless they perceive those rules are backed up by a credible enforcement policy." 30 Much more often, however, it has been extremely difficult to monitor patterns of rule enforcement. This difficulty is exacerbated by the decentralized nature of many enforcement decisions. More to the point of the McNollgast analysis, enforcement procedures are almost never directly addressed in statute drafting.

At each of these stages, the agency can make decisions outside the procedural constraints the statute establishes for rule enunciation itself, and decisions at each of these stages can deflect final agency policy away from the desires of the enacting coalition. Decisions may be made under conditions that may or may not mirror the political environment that surrounded the enacting Congress, and those conditions may or may not stack the deck in the direction of the successful coalition. Monitoring will be more or less effective depending upon those conditions.

Drawing an accurate picture of the significance of agency selection of procedure, then, entails an examination of agency behavior at each of these stages in the translation of congressional policy into influences on private behavior, and drawing such a picture is itself a necessary prelude to understanding the true significance of congressional selection of procedural instruments.

29. See infra text accompanying ntoes 40-43.

30. We Need a Credible EPA, 129 CHEMICAL WK. 33 , Oct. 21,1981 , at 3. 
In emphasizing the retention of procedural discretion by the agency, we remain in agreement with the general thrust of the McNollgast insight: Congress does select among procedural devices in order to facilitate monitoring and channeling of agency action. We want to emphasize that agencies may continue to possess considerable procedural discretion even after Congress has selected procedures with their policy significance in mind. The second part of this article examines that discretion in the case of the EPA's implementation of RCRA. First, in the concluding part of this section we provide the story of RCRA's evolution in Congress in McNollgast terms.

2. RCRA and the Congress. RCRA was enacted at the end of the 94th Congress, in $1976 .{ }^{31}$ It was the last significant federal pollution control statute passed in the 1970s. At the time, the Toxic Substances Control Act ("TSCA"), ${ }^{32}$ which drew considerably more public and interest group attention, was also being debated in Congress. RCRA was the less publicized and contested of the two bills, but the same political forces were at play in its development as in TSCA's drafting. ${ }^{33}$ Although the EPA had been established in large part to keep environmental law implementation free from traditional special interest group capture, environmental groups in the mid-1970s were concerned that the EPA was acting too slowly in enunciating and enforcing rules under the earlier laws. Pro-regulatory forces thus insisted on legislation with provisions that compelled the EPA to act. Accordingly, RCRA contained a number of statutory deadlines that gave environmental groups strong monitoring and some channeling capabilities in the implementation process through their ability to initiate deadline litigation should the agency fail to act.

However, by the mid-1970s, environmental fervor did not completely dominate the policymaking process. As already suggested, President Ford was not well-disposed toward creating more regulation, and the costs environmental controls were imposing on the economy were receiving a great deal of attention. RCRA also contained provisions that evidenced the significant influence existing TSD facility operators had on the process, an influence that seems undeniable in a bill that passed the Senate by voice vote and the House $367-8 .{ }^{34}$ First, implementation was to proceed under a procedure that granted existing facilities

31. 42 U.S.C. $\$ \S 6901-6992$ (1988).

32. 15 U.S.C. $\$ \S 2601-2671$ (1988).

33. Note that TSCA comes easily into focus through a McNollgast lens. It was a statute that had been debated for five years before passage, as the opposing forces around the bill had produced a legislative stalemate. The bill contains potentially powerful regulatory tools, but they have never been vigorously employed by the EPA, in large part because the statute is so procedurally complex. These procedural sections were drafted strategically, so that once the substantive and procedural provisions are read together, the net result is a bill that does not tilt strongly either in the direction of environmental protection or in the direction of permissively sanctioning industrial manufacture of toxic substances. Instead, it mirrors the closely divided political environment present when the statute was enacted, in which environmental protection sentiment was substantially offset by the opposition to new regulations on business of President Ford and his supporters in the Congress. RAY M. DRULY \& GIRARD L. ORDWAY, THE TOXIC SUBSTANCES CONTROL ACT (1977).

34. Congressional Quarterly AlmanaC: 94TH CONGRess, 2ND SESSion 199 (1976). 
"interim status" to operate, provided only that they registered with the EPA. Interim status meant that such facilities could continue their existing operations unchanged until the EPA first wrote permitting requirements and then processed their applications-a process that was to take more than ten years for a number of facilities. Interim status removed any incentive waste disposal facilities users and operators might have otherwise had to cooperate with the EPA to complete the rule enunciation responsibilities under the 1976 Act.

Second, the EPA's need to write comprehensive rules for the entire waste disposal industry gave powerful advantages to the industry, whose representatives provided such a wealth of information about how the industry was multifaceted, and regionally and technologically differentiated, that the EPA was nearly paralyzed in the early rulemaking stages. Deadlines for rule enunciation came and passed. In 1978, the Environmental Defense Fund and several other groups filed suit to compel the EPA to issue the Subtitle C regulations necessary to institute the nationwide permitting system. ${ }^{35}$ While the statutory deadline had passed, the federal court did not have any practical tools available to compel agency compliance. It could not simply write the regulations itself and order the agency to issue them. Holding individual agency officials in contempt was a theoretical possibility, but courts are extremely reluctant to resort to this drastic measure, especially when the agency presents good faith reasons for the delay. ${ }^{36}$ Eventually, the parties and the court negotiated a rulemaking schedule. It, too, was extended several times before a series of rules were issued in 1980 and early 1981 to establish the permitting program. ${ }^{37}$

At this point in the story, it seems very unlikely that the EPA's slow implementation of RCRA deviated very substantially from the preferences of the closely balanced enacting coalition. This assessment seems particularly accurate in the case of the EPA's implementation of the hazardous waste provisions of Subtitle C, provisions that have become the most controversial of the statute, but which received very little attention. The bill's environmental proponents were much more interested in stressing the recycling and reclamation features of the bill, as reflected in the name of the act itself. The cradle-to-grave monitoring system established by the law was understood by all as a significant legislative measure, but there was no widespread rejection of landfills as a means of disposing of hazardous wastes once minimum technological standards had been met. Moreover, TSD facilities had not yet become a focal point for the not-inmy-backyard phenomenon.

For his part, President Ford had in the mid-1970s resisted expensive changes in both the Clean Air and Clean Water Acts, ${ }^{38}$ and did not agree to TSCA until

35. Illinois v. Gorsuch, 530 F. Supp. 340 (D.D.C. 1981).

36. The EPA had several good faith explanations for the delay. The task had proven much more complex than the EPA had supposed-the deadlines were unrealistic. Congress had given the EPA many, many environmental responsibilities in addition to RCRA implementation, and the EPA had made a prioritizing judgment that other statutes demanded more attention.

37. See 42 FED. REG. 2802 (Jan. 12, 1981); 45 FED. REG. 76,630 (Nov. 19, 1980).

38. 42 U.S.C. $\$ \S 7401-7642$ (1988) ("CAA"), 33 U.S.C. $\$ \$ 1251-1387$ (1988) ("CWA"). 
it had been modified to reduce its compliance costs. Industry proponents in the House and Senate thus had strong bargaining positions to resist costly hazardous waste controls, even if environmentalists had been much more mobilized with respect to RCRA than in fact they were. In sum, the EPA's relatively lax pace of implementation and its direction of scarce agency resources to other programs was tolerably close to the policy preferences of the 94th Congress. As of the early $1980 \mathrm{~s}$, there was, apparently, not enough bureaucratic drift to take the EPA's policy outside of the pareto triangle created by the preferences of the House, the Senate, and the President.

Part of the McNollgast thesis is that the monitoring and channeling functions of procedures operate to reduce the likelihood that agency implementation will drift outside that triangle. Indeed, Shepsle has suggested that in the normal case, agencies with ideal points lying outside the triangle will treat the triangle as a constraint and will optimize by picking the nearest policy point on the triangle's boundary-thus avoiding reversal by the coalition-and that the various monitoring and channeling procedures built into statutes enable the Congress to send effective signals to agencies that stray from the triangle. ${ }^{39}$

From time to time bureaucrats may conclude that their interests are served by defying warning signals from Congress, perhaps because they are pursuing agendas that place high value on the short-term gains of such actions, or perhaps because they are supported by an ideological constituency that values that gesture of defiance. The possibility of simple miscalculation cannot be ruled out, either. Whatever the underlying causes, there is some reason to suppose that in the early days of the Reagan Administration, the EPA's implementation of RCRA (as well as Superfund) drifted outside the policy triangle and thus made the statute vulnerable to amendment.

Less than two years into the Reagan Administration, the Assistant Administrator in charge of RCRA and Superfund, Rita Lavelle, was accused of political manipulation of the program, of making "sweetheart deals" with contributors to the President's election committee, and of using contracts to reward and punish legislators. ${ }^{40}$ In addition, EPA Administrator Anne Gorsuch had expressly adopted a nonconfrontational implementation approach for all of the EPA's programs, RCRA included-an approach that many felt translated into woefully inadequate enforcement. ${ }^{41}$ To compound matters, Lavelle continued to espouse the safety of landfilling hazardous materials even after the EPA scientists had testified before Congress that virtually all landfills leak eventually. ${ }^{42}$

39. Kenneth A. Shepsle, Bureaucratic Drift, Coalitional Drift, and Time Consistency: A Comment on Macey, 8 J.L. ECON. \& ORG. 111, 113-15 (1992).

40. House Subcommittees Begin Reviewing EPA Documents; Two More Officials Are Fired, Cong. Q. WKLY., Feb. 26, 1983, at 412.

41. Congressional Quarterly Almanac: 97Th Congress, 2ND SEssion 453 (1982); CONGRESSIONAL QUARTERLY ALMANAC: 98TH CONGRESS, 1ST SESSION 453 (1983).

42. Hazardous Waste: Lavelle Says Land Disposal Regulations 100 Percent Effective in Protecting Public, 13 Env't Rep. (BNA) 1444-45 (Dec. 14, 1982). 
It is ultimately difficult to isolate the extent of bureaucratic drift, however, because during this same period the preferences of majority coalitions in both the House and the Senate were also changing. In both bodies, the median legislator was adopting a dramatically more skeptical attitude toward landfilling wastes than was reflected in the 1976 RCRA legislation, as well as a preference for stiffer technology standards, and fewer loopholes than the 1976 law allowed. These shifts had been propelled by commentary such as that of the EPA's scientists. ${ }^{43}$ Even more significantly, incidents such as Love Canal, the Valley of the Drums, and Times Beach had inflamed public sentiment about negligent disposal practices and heightened the public's fear of exposure to toxic substances. Laxness and loopholes in RCRA regulations were argued to be contributing to the continuing creation of such sites, thus contributing to an ongoing clean-up problem. In particular, public sentiment against land disposal had shifted from the 1970s to the $1980 \mathrm{~s},{ }^{44}$ such that RCRA's apparent neutrality toward different disposal technologies was out of step with widespread public sentiment.

As a cumulative result of bureaucratic and coalitional drift, by the early 1980 s the EPA's policies had come to be located well outside the preferences of the present House and Senate, so much so that Congress was able to revisit RCRA. Over President Reagan's initial resistance-a resistance that waned as the 1984 elections neared-Congress passed the HSWA, revamping both substantive hazardous waste policies and the procedural constraints under which the EPA implements them.

Figure 1 summarizes this legislative and agency history. The apexes of the triangle closer to the origin represent the ideal points for President Ford (P) and the House $(\mathrm{H})$ and Senate $(\mathrm{S})$ of the 94th Congress. The apexes of the triangle farther from the origin represent the ideal points for President Reagan $\left(P_{1}\right)$ and the House $\left(\mathrm{H}_{1}\right)$ and Senate $\left(\mathrm{S}_{1}\right)$ of the 98th Congress. President Reagan's ideal point has moved less from his counterpart's than those of the two branches of Congress, as indicated by his opposition to HSWA.

The initial agency implementation point, that is, the agency's chosen position, $\mathrm{A}$ is depicted as within the policy triangle established by the 1976 legislative and executive actors. By 1981, that point had drifted at the very least to the left most boundary, and was likely to the left of the boundary $\left(\mathrm{A}^{1}\right)$. Compounding the friction between the EPA and Congress, the policy preferences of both bodies had moved up and to the right during this same time period, as indicated by the second triangle. As a result, HSWA become a viable legislative response, and the agency was directed to adopt position $A_{1}$.

If this account is sound, it provides some support for a suggestion first made by Horn and Shepsle in their comment on a McNollgast article. ${ }^{45}$ They

43. Id.

44. Richard C. Fortuna \& David J. LenNett, hazardous Waste Regulation: The NeW ERA 199 (1987).

45. See Horn \& Shepsle, supra note 2. 
suggested that the enacting coalition faces a trade-off between controlling bureaucratic drift and coalitional drift. Devices that provide the enacting coalition's legislators easier influence over agency policy in order to protect against bureaucratic drift also provide easier means for new legislative coalitions to exert their influence, should there be a coalitional shift in the Congress. Thus, increasing insurance against bureaucratic drift can decrease protection against coalitional drift.

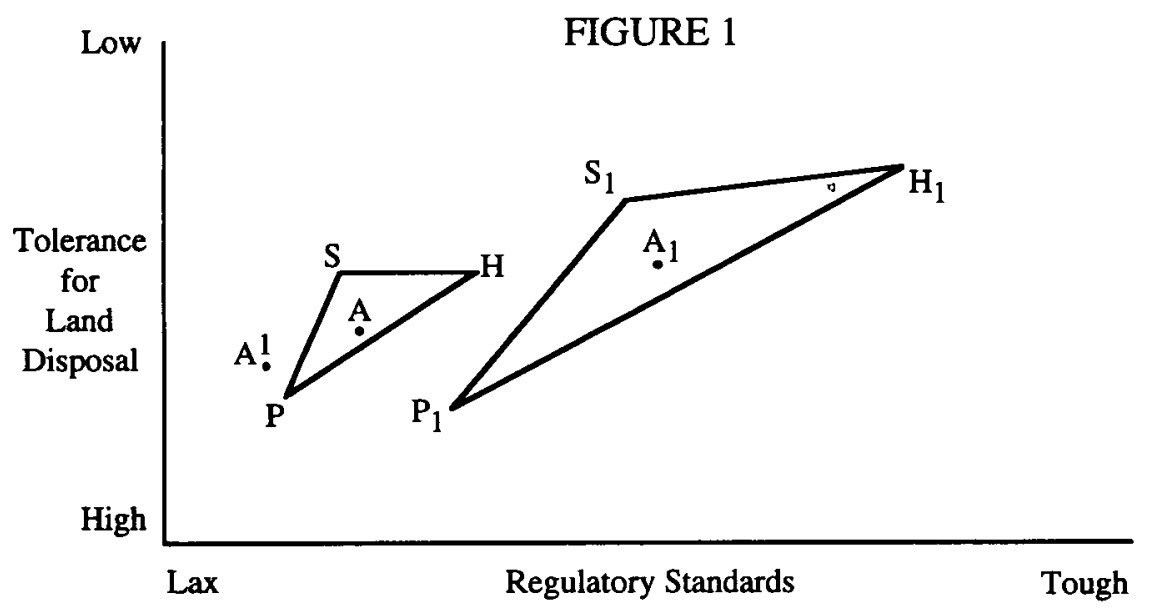

The RCRA experience seems to bear this out. Beginning in 1980, Congress engaged in extensive and intensive ex post monitoring of the EPA's behavior, holding numerous oversight hearings, commissioning and issuing critical studies, and jawboning. These devices were largely ineffective; if anything, the EPA policy under Administrator Gorsuch drifted further away from the policy preferences of the legislative coalition during this period, members of which were themselves shifting markedly away from those of the 1976 enacting coalition. Whether advertently or not, the 1976 coalition had created conditions that protected the EPA from a good deal of congressional influence, meaning that the enacting coalition would have had a difficult time correcting for bureaucratic drift, but also implying that the agency was relatively protected from the demands for policy change created by coalitional drift.

As we have suggested already, in 1984 HSWA altered both the substance and the procedural constraints applicable to the EPA's implementation of RCRA. The new enacting coalition rewrote the substantive provisions of the law to reflect its policy preferences for tougher standards, for fewer regulatory loopholes, and for the use of landfilling only as a last resort. On the substantive side, RCRA was at the time the most detailed and substantively specific statute 
Congress had ever enacted in the environmental field, although it has since lost this mantle to the 1990 Clean Air Act Amendments. ${ }^{46}$ Reacting to its recent experiences of the EPA intransigence, Congress also imposed additional procedural constraints as means of ex ante control against bureaucratic drift. The act continued numerous additional deadlines, and statutory hammers reduced the value of delay to the agency.

The RCRA/HSWA story affirms important aspects of the McNollgast thesis. ${ }^{47}$ In addition, it demonstrates Congress's ability to learn from experience and to make adjustments to procedure on the basis of historical awareness of how the EPA was able to deviate under previous procedural constraints.

The remainder of this article stresses an additional feature of the RCRA/HSWA story: notwithstanding congressional efforts to control agency policy drift through increasingly detailed procedural constraints, the EPA has had, and continues to have, considerable discretion to select, among a range of available procedures, methods of implementing the hazardous waste program.

\section{TEST DEsIGN}

Our tests combine theories from political science, economics, and law with data from the EPA's hazardous waste program to investigate the degree to which regulators are strategic in their choice of whether to issue rules formally or informally. In the PPT literature originating with McNollgast, administrative procedures serve as "instruments of political control" in the relationship between Congress (multiple principals) and regulators (the agent). The substance of rules issued by agencies is, in part, affected by the provisions for interest group monitoring and input made possible by the notice-and-comment process of rule promulgation in the Federal Register ${ }^{48}$ Congress is portrayed as influencing regulatory outcomes by structuring the rulemaking process (for example, by determining who has the burden of proof in the setting of a regulatory standard in a particular program). This description of rulemaking, however, ignores the possibility that regulators may also be strategic in their use of administrative procedures. The crucial insight here is realizing that agencies may choose to avoid the issuance of formal rules through the notice-and-comment process, and instead produce "informal rules" through such devices as agency directives, guidance documents, and policy memoranda. Even when Congress writes specific constraints into the notice-and-comment rulemaking mechanism, it seldom, if ever, completely forecloses the option of informality for the agency.

46. 42 U.S.C. $\$ \$ 7403-7651$ (Supp. 1990).

47. Daniel Farber, Politics and Procedure in Environmental Law, 8 J.L. ECON. \& ORG. 59 (1992). Its story also seems consistent, on the supply side, with the kind of account Farber has given of the production of tough, as opposed to symbolic, environmental legislation.

48. For empirical tests of interest group influence on another EPA regulatory program, one dealing with industrial effluent discharge standards, see WESLEY A. MAGAT ET AL., RULES IN THE MAKING (1986). 
Here, we are using "formal" and "informal" in ways different from their standard usage among students of administrative law. In administrative law, formal rulemaking refers to agency procedures that closely resemble those of a civil court of law, while informal rulemaking consists of more simplified procedures that have come also to be called notice-and-comment rulemaking. In our terminology, both these types of rulemaking are "formal." We reserve the term "informal" rulemaking to describe those devices just mentioned through which the agency issues policy statements or interpretations without engaging in either formal rulemaking or notice-and-comment rulemaking. ${ }^{49}$

This section models the decisions of one set of regulators, EPA officials responsible for issuing rules to implement RCRA, in the selection process they face when choosing the format in which to issue a rule. Hypotheses about what drives the decision of whether to issue a rule formally or informally are derived from two disparate literatures, the "make-or-buy" economics literature in industrial organization and the legal scholarship on the optimal precision of rules.

The economic literature on whether a firm makes a product internally or buys it on the open market provides some explanatory power for regulators' behavior; in issuing a rule an agency faces the decision of whether to "make" its own rule through a policy memo or guidance document or to use the political "market" to generate the rule through the formal notice-and-comment process. Transaction costs economics predicts that whether a firm makes a product or buys it on the market will in part depend on the transaction costs of managing production and purchase relationships. ${ }^{50}$ Transaction costs may arise because of bargaining problems and incomplete contracting. If specialized knowledge or assets are developed, then this may give rise to the prospect of opportunism on the part of the outside producer (for example, this producer may gain knowledge through production, which cannot be replicated easily on the open market) or on the part of the consumer (for example, if a producer invests in specialized equipment that has a lower value to other customers, the customer may attempt to renegotiate an agreement after the assets are sunk). A key point is that incentives to live up to agreements depend in part on the existence of an outside market that defines the opportunities available to buyers and sellers. Taking production inside the firm involves its own costs, such as increases in monitoring and administration. ${ }^{51}$

49. See generally Robert A. Anthony, "Well, You Want the Permit, Don't You?" Agency Efforts to Make Nonlegislative Documents Bind the Public, 44 ADMIN. L. REV. 31 (1992); Robert A. Anthony, Which Agency Interpretations Should Bind Citizens and the Courts?, 7 YALE J. ON REG. 1 (1990); Michael Asimow, California Underground Regulations, 44 ADMIN. L. REV. 43 (1992).

50. Ronald CoAse, The Firm, THE MARKET AND THE LAW (1988); Oliver E. Williamson, THE ECONOMIC INSTITUTIONS OF CAPITALISM (1985); Paul L. Joskow, Contract Duration and Relationship-Specific Investments: Empirical Evidence From Coal Markets, 77 AM. ECON. REV. 168 (1987); Benjamin Klein et al., Vertical Integration, Appropriable Rents, and the Competitive Contracting Process, 21 J.L. \& ECON. 297 (1978).

51. The variables that increase the costs of using the market to purchase a good often also increase the costs of internal production. Hence arguments about the transaction costs of firm versus market production are often about the relative increases in costs (for example, what happens to the value of 
A second source of hypotheses about agency rulemaking incentives is the legal literature on the optimal precision of rules, especially Professor Diver's framework for analyzing regulatory precision. ${ }^{52}$ Professor Diver defines three measures of regulatory precision: transparency (does the rule have an accepted meaning); accessibility (is the rule really applicable in the real world); and congruence (does the rule achieve the desired results). In assessing the relative costs and benefits of the degree of precision involved in the enunciation of a rule, Diver says that one should take into account such variables as the rate of compliance, the over- or under-inclusiveness of a rule, the costs of rulemaking (including information gathering and securing agreement among participants), and the costs of applying a rule (including costs of dispute resolution).

These theories about administrative procedures, firm versus market production, and optimal precision of rules can be combined into a model in which regulators face the decision of whether to produce a rule internally through the issuance of a guidance document or policy memo, or to use the "political marketplace" to produce a formal rule. We view the generation of an informal rule by regulators as analogous to the decision by a firm to make a product internally; whereas we view the notice-and-comment process of publishing a formal rule in the Federal Register as using a political market in which the rule that emerges is influenced by interactions among interest groups that comment on the rule, congressional staff that monitor agency output, executive branch members such as OMB staff that review proposed regulations, and courts that appear likely to intervene. Just as characteristics of specific products influence whether a firm will rely on the market or internal production,

\footnotetext{
"costs of market purchase-costs of internal production" when a given factor changes). Factors thought to favor internal production over market purchase include transaction specificity (the more specialized the product or capital involved, the more rents are created and hence the more the firm chooses to avoid being at the mercy of outside providers), uncertainty and complexity (which make complete contracts in market transactions harder to write), and similarity of transactions (if similar actions are already performed in-house this makes internal production of a given good cheaper). The theory predicts that a firm will take more precautions in choosing the governance relationship of a firm's internal hierarchy or a market's contractual obligations as the complexity of the transaction increases, as the dollar value of the transaction increases, and as the amount of price competition on the open market for the good decreases.

Recent research in industrial organization has empirically examined the "make or buy" decision by taking a sample of parts used in production in a given industry and testing whether one can predict if the firm will have produced the part internally or purchased it in a market. Scott E. Masten, The Organization of Production: Evidence from the Arrowspace Industry, 27 J.L \& ECON. 403 (1992); Scott E. Mastin et al., The Costs of Organization, 7 J.L. ECON. \& ORG. 1 (1991); Kirk Monteverde \& David $\mathrm{J}$. Teece, Supplier Switching Costs and Vertical Integration in the Automobile Industry, 13 BELL J. ECON. 206 (1982). Variables included in these empirical tests of firm decisions to produce or purchase include survey estimates of engineering intensity involved in designing a part (with the hypothesis being that the higher the technical skill required, the more likely production will take place inside the firm because of specialized knowledge created), systems' effects and relatedness of parts (the firm will be more likely to build a part internally if it is a component of a larger system built in-house), and design specificity and complexity (the firm will be more likely to produce in-house if the part is to be used by one company only). The framework for examining a sample of products can be extended to investigating a sample of agency rules and determining what characteristics lead to the production of some rules "informally."

52. Colin S. Diver, The Optimal Precision of Administrative Rules, 93 YALE L.J. 65 (1983).
} 
the characteristics of different types of rules will influence whether regulators will behave strategically. Our specific hypotheses are:

1. As transaction costs of securing an agreement go up, an agency will be more likely to use informal rulemaking. Though few regulations go through an explicit negotiation process in their formulation, the ability of interest groups to challenge rules in court and seek revisions through congressional action, combined with the requirement that agencies respond to comments in their formulation of final versions of formal rules, mean that the notice-and-comment process can take on the trappings of a negotiation. As transaction costs to striking a deal increase, regulators will be more likely to opt for informally issuing the rule. The transaction costs of securing an agreement may rise with increases in the complexity of a rule, the number of parties affected, the heterogeneity of interests, and the degree of technical uncertainty associated with a standard. ${ }^{53}$ As the political and regulatory costs for a rule increase, resistance to agency action may increase, creating additional transaction costs in the formal rule process. The agency's transaction costs in issuing formal rules include staff time and resources expended in complying with the notice-and-comment process. According to an optimistic timetable of goals for promulgating hazardous waste regulations, developing and publishing a "high priority" rule may take at least two years of planned internal work group meetings, agency and OMB review, public comment, revision, and final publication. ${ }^{54}$ Hypotheses about transaction costs relate to the agency's desire to conserve its resources in the development of rules. The EPA's experimentation with regulatory negotiations that bring interested parties together to produce a consensus that may form the basis of a notice of proposed rulemaking demonstrates a desire to reduce agency transaction costs.

2. As the political costs of adopting a given rule increase, an agency will be more likely to use informal rulemaking. Rules that provoke interest group responses that may lead to court challenges or congressional action to overturn agency action are more likely to be issued informally in order to make such politically costly reversals less probable. For a given rule, the political costs perceived by the agency will also depend on the policy distance among the points favored by regulators, courts, and members of Congress. The greater the uncertainty associated with the political market, in terms of the ability to predict the type of rule that will emerge from the formal publication process, the more the agency may try to avoid the traditional notice-and-comment rulemaking path.

3. As the regulatory costs imposed on parties increase, the more likely the parties will resist and, hence, the more likely the agency is to use informal rulemaking. Industry interest groups may attempt to weaken costly formal rules

53. Kathleen Bawn, Political Control versus Expertise: Explaining Differences in Administrative Arrangements (1992) (unpublished manuscript, on file with the authors).

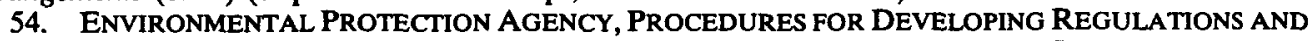
Guidance Documents, OfFice of SOld WASTE AND EMERGENCY Response, POLICY Directive \#9435.00-1 (Office of Solid Waste, 1987). 
by commenting on them during the formal rulemaking process or by challenging them in court. Similarly, environmentalists may attempt to strengthen provisions through submissions and court challenges. Regulatory costs for industry include expenditures arising from compliance and enforcement actions, while costs for environmentalists may relate to the potential environmental damages posed by the activity regulated. The more at stake for regulated parties and other intervenors, the more likely the agency may be to issue the rule informally. Issuing a costly rule through the informal process has several advantages for the agency: it makes input from interest groups less likely than under the formal process; reduces the ease with which Congress may monitor agency performance and hence lessens the ability of interest groups to "pull the fire alarm" on agency actions; lessens the probability that an interest group will be able to challenge the rule in court as informal rules lack the long administrative records of formally published rules; and enables the agency to alter costs of compliance for particular parties since informal rules may be applied with more discretion than formal rules.

4. As concern for uniformity, enforceability, the value of precedent, and the advantages of avoiding individual adjudication increase, an agency is less likely to use informal rulemaking. For some standards, the agency may choose formal rules because their wider publication makes them easier to enforce, they promote uniform standards by reducing discretion on the part of regulators in interpreting and applying the regulations, and they establish predictable patterns of behavior that the regulated party can look to in understanding its property rights under a given regulatory regime. Where the agency values clarity and standardization, such as in highly technical rules that the agency wishes to apply without variation to a large number of facilities, formal rules may thus be favored. To the extent that the application of an informal rule at a regulated facility may involve negotiations that are similar to adjudication, regulators may prefer formal rules because they avoid the costs of these individual negotiations.

5. As congressional specificity in a statute and willingness to monitor its implementation increase, an agency may be more likely to use informal rulemaking. Though Congress delegates much discretion to agencies in formulating regulatory standards, it sometimes signals concern with agency behavior through provisions in legislation that set deadlines for the issuance of formal rules or establish fallback regulatory positions ("hammer provisions") that take effect if the agency fails to act. One reasonable inference might be that as Congress signaled its interest in a particular set of rules, the agency would be more likely to use formal rulemaking since its efforts were being observed. However, one may also view informal rules as an avenue to expand on rules that are formally issued. Hence, as congressional activity in monitoring a particular rule increases, we hypothesize that this may lead regulators to be more likely to use informal rulemaking to avoid the public, political marketplace battles that occur with the notice-and-comment process. Even though a formal rule may be issued to comply with the deadlines and hammer provisions established by Congress, the agency may also issue informal rules that supplement or circumvent the formal 
rule. For example, the agency may issue informal rules in the form of directives and guidance manuals that become the agency's de facto policy even as the agency's official policy is being developed through the issuance of heavily scrutinized notice-and-comment rules.

6. When courts are actively monitoring agency action, the regulators will use informal rulemaking. In areas where the courts signal that they are monitoring agency behavior by issuing deadlines for rule issuance or remanding an issue back to the agency, regulators may be more likely to use informal rulemaking to circumvent this monitoring. As in the case of congressional scrutiny, the agency may respond to court scrutiny by issuing a formal rule. We believe, however, that the additional scrutiny by courts will also lead the agency to issue informal rules that deal with the area involved in litigation. An alternative hypothesis is that in a post-Chevron world of court deference to agency action, regulators may be more willing to use the formal process since their actions are then less subject to challenge in the courts. Our hypothesis is that, on balance, court scrutiny will lead to informality.

We have chosen to examine these six hypotheses about regulators' selection of formal versus informal rules by examining the rules implementing RCRA. ${ }^{55}$ The set of "informal" regulatory requirements associated with RCRA is comprised of three separate types of "rules." The EPA's Office of Solid Waste and Emergency Response ("OSWER") has issued a large series of directives that help explain agency policies to regional offices, state environmental agencies (who play a large role in hazardous waste regulation since parts of RCRA are delegated to states for enforcement), and the public. The OSWER documents range from short policy memos to guidance documents numbering hundreds of pages. These documents have been compiled by the EPA so that interested parties have a single, comprehensive source for the requirements under RCRA. ${ }^{56}$ Many of the documents have been given wider circulation by the EPA through their publication by the National Technical Information Service. While the agency's output of OSWER directives began to drop off after 1988, the Regulatory Development Branch (the "RDB") of OSWER continued to provide regulatory interpretations about RCRA. The private consulting firm McCoy Associates requested the memos, dubbed the "RDBs memos," under the Freedom of Information Act and cross-referenced the approximately 1,700 pages

55. One reason the RCRA program was chosen is that since part of the regulatory activity centers around the negotiation of permits for facilities that treat, store, or dispose of hazardous waste, there is room for regulators to exercise discretion as to what is incorporated in the "regulatory contract" at each facility. The necessity of having an operating permit to continue the operation of a hazardous waste TSD facility and the prospect for future regulatory interactions in inspections and enforcement actions may provide the EPA with the leverage to require firms to adhere to "rules" that have not been formally promulgated but which the agency treats as its standards in permit negotiations and enforcement actions. A second reason for selecting this set of regulations is that a private consulting firm has undertaken the task of cataloguing the "informal rules associated with RCRA" and cross-referencing them with the Code of Federal Regulations.

56. Environmental Protection AgenCy, RCRA Permit Policy COMPENdium Update PACKAGE (Office of Solid Waste and Emergency Response, 1992). 
it received in reply. Together with the OSWER directives, the firm estimates that its RCRA index covers over 900 documents with nearly 19,000 pages of requirements in the form of "letters, guidance manuals, and directives." 157 A third source of information about the EPA's "informal rules" is the publication by the EPA of its responses to questions about interpreting hazardous waste regulations. The EPA RCRA/Superfund Hotline is set up to answer questions from the regulated community about interpretations of hazardous waste laws and regulations. The EPA circulates a monthly internal report on the Hotline which includes questions and responses that provide clarifications of agency policy. McCoy and Associates has collected these responses, published them, and crossreferenced them with the Code of Federal Regulations (the "CFR") to provide a third set of interpretations (over 260 separate Hotline responses) of the agency's rules for generation or handling of hazardous waste.

One test to determine the degree of formality of rule selection would be to examine the characteristics of each of the informal rules set forth in the EPA's directives and the formal rules implementing RCRA contained in the CFR. We have chosen the computationally simpler path, however, of using the crossreferencing of these formal and informal rules to answer the following question: what characteristics of the formal hazardous waste rules published in the CFR predict whether there will be informal rules addressing the same regulatory requirements as the formal rules? This inquiry ignores those informal rules not cross-referenced with the CFR; it also assumes that the contents of the informal rules are similar to their formal cross-referenced CFR counterparts. This formulation has allowed us to structure a way to test many of the theories of administrative procedures within this particular rulemaking program.

The unit of observation for our tests is the decimal point CFR number (for example, 261.31 is treated as an individual rule, as is 261.32). This division yields a total of 697 formal rules in the CFR sections implementing RCRA. We created a coding sheet, which several law students used to classify the substance of these rules according to the categories described below. After the contents of the formal rules were coded, the data were merged with the list of informal rules so that we were able to determine which formal CFR decimal point rules had "informal" counterparts in OSWER directives, RDB memos, and Hotline responses. Our main tests were logistic regressions which modeled the characteristics of the formal CFR rules that influenced which rules had "informal" rules that added further requirements. Since the majority of the pages of requirements were contained in OSWER directives, the analysis focuses on models of which types of rules were supplemented by informal rules contained in OSWER directives.

Out of 697 formal RCRA rules analyzed, 210 had at least one OSWER directive associated with their regulatory requirements. The dependent variable

57. MCCOY AND ASSOCIATES, MCCOY'S INDEX OF RCRA REGULATORY INTERPRETATIONS i (1992). 
in our logistic regression was equal to 1 if the formal CFR rule had at least one OSWER directive associated with it and 0 if there were no OSWER directives associated with it. The independent (that is, explanatory) variables were designed to reflect the hypotheses about what types of rules were more likely to be issued formally or informally by regulators.

Table $1^{58}$ presents the list of variables and their definitions. Each decimal point rule dealing with RCRA in the CFR was examined and analyzed according to the following categories:

Rule requirements: Every rule was classified into at least one requirements category depending on what the rule required the facility operator to do or allowed the agency to do. Rules were thus classified depending on whether they dealt with the provision of existing information, provision of new information, testing or monitoring, expenditures on specific physical or human capital, enforcement actions or inspections, financial requirements, closure or postclosure issues, corrective actions (that is, cleanups), or definitions of the scope or applicability of a rule. The expected signs for these variables will depend on the interaction between transactions costs of securing agreement on the requirement, the political costs associated with the requirement, the compliance costs, and concerns about enforceability and the value of avoiding individual negotiations and adjudications with the application of the rule at a facility.

Rules requiring the provision of existing information or requiring testing may be issued through the CFR because they tend to have relatively low compliance costs. Concern for enforceability if court disputes arise and a need to establish wide understandings among the regulated community may make it more likely for regulators to issue definitions and technical standards formally. Provisions relating to enforcement actions by the agency, cleanup standards in the event of contamination at the hazardous waste facility, and closure requirements may be more likely to be supplemented by informal rules, because these rules are politically controversial, entail large costs for the regulated community, and often involve interactions between regulators and facility operators in which the agency may wish to preserve discretion through the application of "informal" rules.

Specific technologies: If the rule focused primarily on provisions affecting a specific technology for handling hazardous wastes, then the provision was classified according to whether it dealt with the technology of container storage, tanks, waste piles, surface impoundments, incinerators, landfills, land treatment, or miscellaneous technologies such as drip pads. Hypothesized signs for these technology dummy variables related to the number of facilities, amount of waste handled, and controversy in terms of environmental hazards and compliance costs associated with the waste handling method. The higher the number of facilities using the technology, the more likely the agency would be to issue a rule formally so that it did not have to engage in numerous negotiations about the interpretations of informal rules at a large number of facilities when the rules

58. All tables referenced in this article can be found in the Appendix at 149-60. 
were applied. ${ }^{59}$ The same logic may apply to amounts of waste; if a technology is widespread and the agency issues formal rules to avoid individual enforcement negotiations with numerous facilities this may mean that larger amounts of waste are covered by formal rules. The more controversial the technology in terms of its perceived health effects, the more likely the agency is to avoid the formal process and deal with the facilities through informal rules. The threats posed by groundwater contamination from landfills and the debate over the risks associated with incineration mean that the agency may be less likely to use the "market process" of formal notice-and-comment rulemaking to set standards relating to these technologies.

Related variables include what types of facilities are regulated by the rule. Given the large number of generators, the agency will be likely to issue rules covering these facilities formally to avoid numerous interpretations of rules; since commercial facilities that process waste generated offsite are fewer in number, the agency may be more likely to issue informal rules relating to these facilities.

Rule History: A separate set of hypotheses relates to the interactions among Congress, the agency, and the courts. When the rules are enunciated in their final form in the Federal Register, the EPA often recounts the history of the rule's promulgation, including actions taken by Congress and the courts. We have constructed dummy variables relating to the rule histories, which entail several caveats. First, the rules announced often come in bundles (for example, multiple CFR decimal point rules are announced together), so that it is difficult to determine which rule among the several announced was the subject of the congressional action. We adopted the coding convention that for a given set of rules announced in a Federal Register listing, the legislative and judicial history would be applied to the entire set of rules for that day. Second, we assume that significant legislative and judicial actions have in fact been included in the agency's introduction to the rulemaking. Third, a given rule may go through multiple revisions during its lifetime. Our history variables are coded so that the dummy variable equals 1 if the rule at some time meets the requirement of the specific category (for example, if at least one version of the rule was subject to a court deadline, then the dummy variable for court deadline is 1 for this rule).

Variables dealing with the level of congressional and judicial scrutiny include whether Congress set a deadline with a fallback regulatory standard if the agency did not act (a "hammer" provision), whether Congress set a deadline for rule issuance but did not specify a default regulatory position, whether the courts imposed a deadline for rule issuance, or whether the courts remanded a rule to the agency or the version of the rule arose from court actions such as consent decrees (these latter two actions will be collapsed into the term "court remands" in our tables and discussion). The effect of these actions on the agency's

59. Note, however, that the large number of participants in the formal rulemaking process could make securing agreement at the rulemaking (as opposed to rule application) phase more difficult if the participants had numerous divergent interests. 
procedural decision in rulemaking is an open theoretical and empirical question. Greater congressional and judicial scrutiny may make the agency more likely to show deference to these institutions by issuing the rules formally through the notice-and-comment process. If the agency wishes to circumvent the expressed directions of Congress or the courts, however, regulators may be more likely to issue informally when these groups have signaled interest in a particular set of regulations, because informal rules may be less susceptible to reversal and less likely to result in a reprimand for the agency.

Another part of the preamble and analysis of a formal rule described in the Federal Register is an indication of whether the rule is a "major rule," a designation that triggers a formal regulatory impact analysis and is generally applied to rules with costs of over $\$ 100$ million. Under the hypothesis that the higher the cost of a given rule the more likely the agency will be to act informally to avoid contention in the rulemaking process, we would expect to find more informal rules associated with formal "major" rules. The total number of versions the CFR rule has been through has also been calculated, on the theory that the more controversy surrounding a rule (reflected in part by its number of revisions), the more likely that the agency will supplement it with informal rules. The number of technical corrections is also counted; though here, under the theory that technical issues and definitions may be dealt with formally to provide greater clarity in enunciation and application, the hypothesis is that the greater the number of technical corrections to a rule the more likely it will be that the rule will be issued in a formal version without informal supplement. The action taken by the agency to amend the rule formally may also be an indication that informal documents that would provide further elaboration of the rule do not exist.

Table 2 summarizes the expected signs of these variables' coefficients in a logistic regression examining whether a formal rule is supplemented by an OSWER directive. A "+" indicates that for the given hypothesis the variable will make it more likely that an informal rule supplements the formal CFR rule, while a "-" indicates that the variable makes it less likely that the formal rule will have an informal rule associated with it. In terms of regulatory costs, formal rules with low expected costs (for example, those requiring existing information, mandating testing, or providing definitions) would be less likely to have associated informal rules, while those with high expected costs (for example, those relating to new information, technical standards, enforcement, financial matters, closure, or corrective actions) would be more likely to have associated informal rules. High political and regulatory costs may make the transaction costs of a formal rule in terms of agency time and resources so high that the agency will be more likely to supplement or supplant the formal rule with informal rules. Rules with high political costs include controversial measures such as those relating to enforcement, closures, and corrective action; rules relating to the specific technologies of incinerators (associated with technological uncertainty and air pollution risks) and landfills (associated with groundwater contamination) and certain types of facilities (for example, commercial facilities, 
whose disposal capacity may pose the threat of significant externalities); major rules (which by definition impose large regulatory costs, and will also be politically controversial); and heavily revised rules (whose revisions indicate controversy).

In terms of the application and enforcement of rules, we hypothesize that the agency will be more likely to issue only formal rules where there is a need for wide and precise understandings, such as with rules relating to technical standards or with technical requirements (as indicated by the number of technical corrections) and rules relating to definitions. Where the agency may wish to preserve its discretion, however, informal rules may be issued since they can be more selectively applied. Concern for agency discretion may thus lead requirements dealing with agency enforcement actions or facility closure to be issued in part through informal rules. The higher the number of facilities affected by a rule, the more costly the process of clarification and negotiation associated with the application of informal rules. Hence, if a particular technology is used at a large number of facilities, then the agency's concern about regulators' implementation costs may make it more likely to issue requirements through formal rules only.

Table 3 provides indications of the number of facilities associated with different waste handling technologies and forms the basis of our hypotheses about the relative advantages of rule formats in terms of application costs. Since the technologies of containers and tanks are used in waste management methods at thousands of sites, rules governing these technologies are likely to be formal. Technologies used at fewer facilities, including incineration and landfill, will be more likely to be covered by rules with informal elements since there are fewer facilities to which the agency must apply these rules. Similarly, the large number of generators means these facilities will likely be governed by more formal rules, while commercial facilities (which are fewer in number) may be less likely to be covered by formal rules alone.

Finally, both congressional and judicial scrutiny are assumed to give rise to CFR rules that are associated with formal rules. While this scrutiny may mean that the agency will issue formal rules that are examined by the courts and Congress, we believe that the added monitoring may make it more likely for the agency to issue additional requirements through OSWER directives and guidance manuals.

While we have emphasized that the EPA may choose informal rules to avoid the monitoring and reduced agency discretion associated with the procedures of formal rulemaking, questions remain about whose influence the agency is trying to avoid each time it issues an informal rule and to what end it is using an

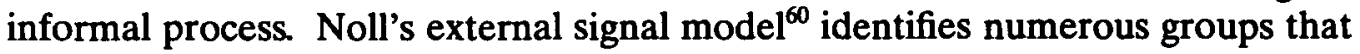

60. Roger G. Noll, Government Regulatory Behavior: A Multidisciplinary Survey and Synthesis, in Regulatory POlicy AND THE SOCIAL SCIENCES 9 (Roger G. Noll ed., 1985). 
have an impact on agency decisionmaking: Congress, courts, executive branch officials, industry participants, and environmentalists. ${ }^{61}$ Though our discussion of informality will often proceed as if informal rules were used to evade these parties, it should be noted that some participants may prefer the agency to issue rules informally to avoid the influence these participants' opponents could exercise in the formal process. For example, members of Congress concerned about the possibility of the OMB delaying the promulgation of formal regulations unless standards imposed on industry were eased might prefer the EPA to issue its rules first through guidance documents and directives less subject to OMB oversight. (By the OMB's own estimate, it caused the content of nearly one-third of the rules proposed by the EPA in 1986 to be changed after they were initially submitted for review. ${ }^{62}$ ) To what end informality is used by the agency also remains an open empirical question in our tests. The agency may use a directive to expand coverage of a rule so that additional costs are borne by industry, or it might narrow an interpretation so that environmental risks are increased. The ultimate impact rule format selection has on environmental outcomes thus remains open for debate. ${ }^{63}$

\section{Id.}

62. OMB Said to have Influenced One-third of Regulations Proposed by EPA in 1986, 17 ENV'T REP. (BNA) No. 1616 (Jan. 23, 1987).

63. There are several objections and qualifications to the above theories, which we will address before presenting the results of our tests. An alternative explanation for the series of guidance documents and policy memos issued by OSWER is that they are simply interpretations of the CFR which really exact no new regulatory burdens; according to this view, these documents are simply making property rights clearer by elaborating on already established rules instead of creating new rules. Our tests can explore this hypothesis, however, for it predicts that there should not be any systematic differences between those formal rules that have informal counterparts and those that do not, except perhaps in characteristics that might require further elaboration. A second possible objection is that these documents should not be called rules because courts would not uphold them as formal requirements for a facility seeking a RCRA permit since the rules had not gone through the notice-andcomment process. We believe that an agency's leverage with hazardous waste facilities, which arises out of the agency's permitting authority and the likelihood of future enforcement interactions between regulators and facility operators, allows it to encourage compliance with its "informal rules" as part of the set of rules governing EPA's expectation of how hazardous waste facilities should operate. The regulatory checklist used by state permit writers negotiating RCRA permits for TSD facilities, for example, includes provisions arising solely from agency guidance documents and not appearing in rules formally promulgated in the CFR.

In developing our hypotheses, which focus on the external parties influencing agency decisionmaking, we have neglected to describe problems facing agency officials relating to the internal agency procedures to be chosen for rule formulation. As Ferejohn has observed, agency officials concerned about decisionmaking delegated to subordinates will design internal review processes that allow for "the collection of information about whether a proposal is likely to evoke controversy in the agency's environment." Ferejohn, supra note 4, at $\mathbf{4 4 6 .}$ The choice between issuing a policy by a formal rule or an informal directive may thus relate to the internal EPA procedures associated with the agency's own review processes for these different types of rules. In a 1987 directive, OSWER outlines how the internal review process of workgroup meetings, interoffice reviews, and senior official involvement will vary for regulations and guidance documents depending on three factors: the scope and cost of the rule; the environmental benefits associated with the requirement; and management concerns, which the document defines in part by a series of questions ("Who are the interested parties, what political or economic pressures are driving the development of the rule, and what are the potential impacts if the Agency does not develop the rule now but chooses to defer or postpone development?"). OFFICE OF Solid Waste and Emergency Response, Environmental Protection Agency, Procedures 
III

RESULTS

Our analysis of the agency's rule enunciation selections under RCRA provides an overview of the number of rules issued, a comparison of formal rules with and without associated informal directives, a logistic analysis of the determinants of rulemaking formality and of court remands, and an examination of what drives the length of informal rules issued. The figures in Table 4 indicate that a large volume of informal rules exist that supplement the formal RCRA regulations promulgated in the Federal Register and that the time pattern of their release differs from that of formal rules. The unit of analysis in counting formal rules was the decimal point rule in the CFR. Under this counting system, 697 new formal rules implementing RCRA were issued from 1980-91. The average formal rule goes through at least two versions, so if one counts each edition of a rule as a separate rule there were 1634 total final RCRA formal rules published in the CFR by our counting system. The largest number of new rules (153) was issued in 1980, and the smallest number (3) was issued in controversy-racked 1984.

For the main source of informal rules under RCRA, the policy memos and guidance documents issued by the EPA's OSWER, McCoy and Associates had

FOR DEVELOPING REgulations AND GUIDANCE DoCUMENTS 14 (1987). The interested parties that those drafting rules are to consider, according to the directive, reads like a who's who of the external signals model: Congress, the OMB, state agencies, environmental groups, citizen groups, and industry associations. The agency's internal process for reviewing rules thus depends in part on the likelihood of external scrutiny, with the more attention attracted outside the agency the more internal review processes envisioned by the OSWER directive on rule development. Our examination of what drives the selection of formal versus informal rules focuses more on the "agency's" calculation of relations with external participants than on how internal review processes differ for formal versus informal rules (which would deal more with the relationships among offices and hierarchies within the agency).

A final note relates to how this test fits into the broader McNollgast view of administrative procedures. Previous work has allowed Congress to be strategic both in terms of its policy positions and in its use of administrative procedures, while regulators were treated as having policy preferences but lacking strategic power to circumvent the instruments of political control established by administrative procedures. In contrast, we treat regulator's strategic power as an open question, and we test the hypothesis that regulators too are able to act strategically with regard to rulemaking procedures, by choosing to avoid the formal rulemaking process and to issue informal rules in the form of policy directives and guidance documents. (As just indicated, we generally do not address the further delegation issues that arise with the hierarchical structure within an agency and hence do not focus on the strategic interactions among multiple regulators within the agency.) The ability of regulators to issue such informal rules arises in part because of slack in the relationship between the multiple principals (members of Congress) and the agent (regulators).

A response to this may be that the amount of informal rules observed simply reflects the degree of monitoring and policing that Congress is willing to undertake. But this is another way to phrase the common result in sophisticated principal-agent models that the amount of slack is endogenous. Given divergent preferences between principals and agents, the amount of monitoring and policing, and hence the amount of slack available for consumption by agents, will depend on the relative benefits of monitoring and enforcing, the costs of engaging in these operations, and the importance of the issues at stake. While members of Congress may thus be aware of the possibilities for strategic action by regulators in the issuance of informal rules, the existence of such rules may indicate the difficulties of Congress in ensuring compliance with administrative procedures rather than its approval of this informal method of rulemaking. 
catalogued over 505 OSWER directives that totaled over 19,500 pages of regulatory "guidance." Nearly half of these directives were issued during 198485 , during which time only seven percent of new rules and thirteen percent of total formal rules were issued. This is inconsistent with the notion that informal rules are issued simultaneously to elaborate on formal rules and consistent with a story of informal rules substituting for formal rules. The pattern is also consistent with informal rules being issued as later additions to formal rules as these rules are implemented and fought over in the field.

There has been a decline in the number of OSWER directives in recent years, although the page numbers issued remain substantial. In the late 1980s, during this decline, the agency began to offer clarifications and elaborations internally through interpretations made in the form of memos by the RDB of OSWER. The McCoy and Associates FOIA request yielded over 1200 pages of these RDB memos. Interpretations of agency positions also increased in the late 1980 s with the publication of written responses to questions received by the agency's RCRA/Superfund Hotline.

Table 5 presents the variable means for the total population and subsamples of RCRA formal rules. One way to investigate the nature of the informal rules is to examine the characteristics of the formal rules with which they are crossreferenced. Comparison of those formal rules that are supplemented by OSWER directives with those formal rules that are not cross-referenced with OSWER directives reveals clear differences between the two groups. If one assumes that the informal rules deal with the same topics as the formal rules cross-referenced with them, as we have, then one can use these figures to compare formal rules with informal rules. In our discussion of the agency's selection of rulemaking procedures, we will often refer to the characteristics of formal rules that have associated informal rules simply as the characteristics of "informal rules." Of the 697 formal CFR rules dealing with RCRA, 210 had associated OSWER directives or guidance memoranda. Table 5 indicates that rules with OSWER directives are more likely to deal with enforcement issues and closure actions at hazardous waste facilities than rules without OSWER directives. About sixteen percent of the rules that are purely formal deal with enforcement actions, versus thirty-two percent of those rules supplemented by informal rules. This is consistent with the hypothesis that the agency might choose to issue informal rules when it wishes to preserve discretion relating to its own activities, such as inspections at facilities and closure proceedings at facilities that have reached the end of their commercial viability or are unable to remain in operation because of failure to meet regulatory standards. Testing and technical standards provisions are more likely to be issued formally, consistent with the greater ease of explicating and enforcing these requirements through clearly enunciated formal rules. Rules relating to containers and tanks are also more likely to be issued formally, while landfill and incinerator rules are more likely to be issued informally (in the sense that a higher fraction of rules with OSWER directives relate to these technologies). 
The degree of congressional and judicial scrutiny is also different for formal versus informal rules. Comparing rules with OSWER directives to those without OSWER directives, one finds that informal rules were more likely to have had a version that was subject to a congressional hammer $(16.7 \%$ versus $11.7 \%$ of rules without OSWER documents), had been issued under a court deadline (17.6\% versus $6.4 \%$ ), or had been the subject of a court remand or consent decree $(46.7 \%$ versus $11.1 \%)$.

These results are consistent with at least three alternative explanations. One explanation is that the agency may wish to issue controversial rules informally, and that these measures of congressional and judicial scrutiny simply reflect underlying controversy. In this scenario, the agency's rulemaking would not necessarily be a reaction to congressional or judicial action. A second explanation is that as a response to congressional or court scrutiny the agency may choose to issue OSWER directives rather than formal rules, because their application and enforcement is harder to monitor. A third explanation would be that the congressional and judicial actions are a response to the rules' issuance as informal OSWER directives. We believe the latter interpretation is the least likely, for lawsuits surrounding the rules that are mentioned in the preamble to the formally enunciated rules do not often mention challenges to OSWER directives. Yet, our data do not distinguish between when the congressional and judicial actions took place and when the OSWER directives were issued. To the degree that our data control for other measures of controversy, such as revisions and costs, then the congressional and judicial action variables can be viewed as relating to reactions to monitoring by those groups. That informal rules appear to be more likely when Congress or the courts are involved in rulemaking establishes necessary, though not sufficient, evidence to prove evasion by the rule writers.

The informal rules (that is, the formal rules that have informal rules associated with them) go through more revisions (3.6 versions) than the rules without OSWER directives (1.8 versions). The formal rules are more likely to have had a technical correction, consistent with the hypothesis that more complex or technical provisions are issued formally. Rules with OSWER directives have a higher number of associated RDB memos (2.6 versus .19) and a higher number of Hotline responses (1.7 versus .24$)$. This raises the question of whether to treat RDBs and Hotline responses as informal rules equivalent to OSWER directives and thus subject to the same generating process within the agency, or to view these two categories as simply reflecting responses to questions of interpretation arising from formal rules. Unlike the OSWER directives, which are often widely circulated and sometimes placed by the agency with the National Technical Information Service for sale and distribution, the RDB memos were internal to the agency and released through a FOIA request (although they are now commercially available from McCoy). The Hotline responses are contained within agency reports that contain information to help personnel understand current interpretations. 
Table 5 offers some evidence that OSWER directives, RDBs, and Hotline responses are different. The most frequent subject of the formal rules supplemented by OSWERs is enforcement $(31.9 \%)$, while the most frequent subject of the RDB rules and the rules involved in Hotline questions are definitions (59.6\% of the RDBs and $34.2 \%$ of the Hotline questions). Hotline and RDB rules are also more likely to be subject to technical corrections, again indicating that these agency responses may be better characterized as traditional interpretive rules that clarify technical issues rather than as new rules that enunciate significant requirements. We will thus focus our examination of informal rules on the OSWER directives; note that of the full sample of 697 formal rules, 210 had associated OSWER directives, 47 had associated RDBs, and 149 were the subject of Hotline responses.

Table 6 provides some additional evidence concerning these relationships among rule types. While the existence of an OSWER directive or RDB memo and the number of Hotline responses are positively correlated for the formal RCRA rules, Hotline responses and RDB memos are more strongly correlated with each other than with OSWER directives. Having an OSWER document associated with the formal rule is positively and significantly correlated with judicial scrutiny and with whether the standard is a major rule. Hammers and congressional deadlines are positively correlated, consistent with the view that these types of congressional scrutiny are related and may be applied to different versions of the same rule at various times in its lifetime. Major rules are positively correlated with court-imposed deadlines and negatively correlated with court remands, perhaps indicating judicial deference on the content of these rules, and that these issues are resolved in rulemaking battles rather than in court battles.

Table 8 allows us to make conclusions about the determinants of agency selection of formal versus informal rulemaking procedures by examining what factors influence whether a formal rule is supplemented by at least one informal rule in the form of an OSWER directive. ${ }^{64}$ The dependent variable in the

64. Before the regression results are examined, one additional question about our model should be addressed. The discussion about whether the agency chooses to issue an OSWER directive or place all requirements in a formal CFR rule has focused on a cross-section of characteristics of the formal rule (e.g., does the rule deal with enforcement? does it apply to tanks? is it a major rule?). Rules also differ, however, in terms of timing (e.g., when was the formal rule issued? when was the OSWER directive issued?). Since the agency's policies and objectives that determine its desire to issue formal versus informal rules may change over time, a question arises about whether the differences that appear to be due to cross-section characteristics are really due more to circumstances when the rule was issued. More specifically, Table 4 indicates that nearly half of the OSWER directives issued were published in 1984 and 1985. Is it the case that the agency appeared to be willing to issue directives and guidance memos more frequently during those two years so that whatever the topics and characteristics of rules issued during that time period, it is these elements that will appear to be the most important cross-section factors in driving the agency's decision? In other words, if 1984 happened to be the year when decisions dealing with characteristic $Y$ came up and the agency was issuing informal rules as a policy during this time period, will it appear that $Y$ is driving the decision in our analysis? The evidence suggests that this is not a problem with our cross-sectional analysis.

There are definite time periods of significant activity in RCRA rulemakings: the Phase I core regulations; Phase II regulations, the remaining core rules (1981-82); and the activities resulting from the 
logistic regression is equal to 1 if the formal rule has an OSWER directive crossreferenced with it. The versions of the model are presented so that sets of variables are added representing what the rule requires, which technologies are covered, what the congressional and legislative interactions have been on the rule, and how controversial or costly the rule is. The coefficients for the variables are similar across the different formulations of the model, so we focus our attention on specification (4), which tests hypotheses relating to all these factors.

Specification (4) indicates that rules dealing with enforcement actions and closure provisions for the facility are, holding other factors constant, more likely to be issued informally than formally relative to rules that provide definitions (DEFN is the omitted requirements dummy variable here). This is consistent with the notion that the agency may wish to preserve its discretion in the interactions and negotiations associated with enforcement actions. Closure provisions, which deal with a facility's ex ante preparation for shutting down and ex post compliance with rules when it is closed, may be issued informally again out of a desire to preserve discretion in dealing with the negotiations surrounding the closure of a facility. Note that these rules deal with actions by the agency, in contrast to the other rules which define the actions taken by the facilities.

The statistically significant coefficients on technology variables indicate that rules dealing with tanks or containers are more likely to be issued formally, that is in rules published in the CFR that are not supplemented by OSWER documents. Rules covering landfills, however, are more likely to be issued informally. Table 3 provides information on the number of facilities and amount

\footnotetext{
Hazardous and Solid Waste Amendments ("HSWA") of 1984, including the codification of 25 statutory provisions of HSWA in July 1985 and the issuance of numerous directives and guidance documents dealing with these amendments. ENVIRONMENTAL Protection Agency, EPA ACTIVITIES AND ACCOMPLISHMENTS UNDER THE RESOURCE CONSERVATION AND RECOVERY ACT: FISCAL YEARS 1980 TO 1985 (1986). Nearly half of all OSWER directives and guidance manuals were issued during 1984-85 (although this accounts for only $23 \%$ of the total pages of these types of informal rules). However, a close examination of the informal rules issued during this period indicates that a wide variety of types of OSWERs were issued. For Table 7, each time an OSWER directive was cross-referenced with a formal CFR rule in the McCoy index, the characteristics of the formal rule (e.g., did it deal with tanks?) were used to categorize the requirements of the directive or guidance document. There are a total of 961 such pairings of formal CFR rules and OSWER directive requirements. Table 7 shows the distribution of these requirements by category type (note that a single OSWER directive may be counted more than once here if it was linked to more than one CFR rule or if the CFR rule with which it was linked dealt with multiple categories of rules). The figures indicate that it is generally not the case that a larger than average fraction of one category of rules had OSWER directives concentrated in 1984-85; rather, most categories of rules had some directives issued during that period. This helps alleviate problems that would arise if a higher than average fraction of a rule type was concentrated in this time period, and this rule characteristic appeared to be a driving factor in the selection of formal versus informal requirements.

As an additional check, we examined the correlation between the rule characteristics and the year the OSWER directive was issued for the set of 961 CFR-OSWER directive pairings. Though the date the OSWER directive was published and some rule characteristics were slightly correlated, the relationship between when an OSWER was issued and what type of rule was involved was generally weak. Any relationships between the characteristics of the formal rules and whether these rules are supplemented by OSWER directives are due to the types of cross-section hypotheses discussed above rather than a coincidence between a policy of informality adopted by the agency and the concentration of rules of a certain type during the 1984-85 period.
} 
of waste streams handled by the technologies. ${ }^{65}$ Tanks and containers are part of management methods at many facilities that handle large waste streams. For example, RCRA-permitted storage, which may involve these two technologies, accounted for 189 million tons of waste (nearly a quarter of waste handling in 1986) and was spread over nearly 1800 facilities. In contrast, landfill technology was restricted to 118 facilities, which managed 3.17 million tons with this technology. The pattern of formal rules for tanks and containers and informal ones for landfills is consistent with the hypothesis that the agency will prefer formal rules when a large number of facilities are involved, because informal rules here might entail numerous regulatory interactions and negotiations for clarification and enforcement. When a smaller number of facilities is involved, however, the agency may prefer to preserve its discretion through informal rules and conduct negotiations over rule provisions with the facilities. The controversies associated with potential groundwater contamination also are consistent with a desire by the agency to use informal rulemaking with landfill regulations, although the direction of the agency's actions here in terms of stringency are not clear. Informality may allow the agency to write stricter landfill standards than those attainable through the notice-and-comment process, or it may allow regulators to write laxer standards than in a formal forum subject to participation and monitoring by environmental groups.

Those rules that are the subject of court remand or consent decrees are more likely to be issued informally. As outlined above, this may mean that increased judicial scrutiny leads to attempts by the agency to circumvent the courts' directives by using informal rules or that informal rules are issued on controversial issues in general and that these types of issues often end in adjudication. Note that court remands are positive and statistically significant even after we control for other measures of controversy, such as the number of revisions. Hammer provisions and court deadlines are also positively related to the selection of informal rules in specification (3), although they are not statistically significant in specification (4) once additional controversy measures are added.

Major rules, which are requirements that impose large costs, and rules that have been revised frequently are also more likely to be supplemented with OSWER directives. This is consistent with the hypothesis that the agency will attempt to impose more costly or controversial requirements through informal rules because they may be unable to achieve similar rules through the noticeand-comment process (or may only be able to achieve such rules in the noticeand-comment process at a larger political price). Time dummies indicating when the CFR rule was issued were added in specification (5) to see if there is a trend in the issuance of informal rules. Time dummy variables for new formal rules issued in 1988, 1989, and 1990-91 were all negative and statistically significant, indicating that these formal rules were less likely to have informal rules

65. See infra page 151. R.D. Baker et al., Management of Hazerdous Waste in the United States, 9 HAZARDOUS WASTE \& HAZARDOUS MATERIALS 1 (1992). 
associated with them. This may be because the agency has shifted away from informal rules like the OSWER directives, or because it takes time for formal rules to be supplemented by informal rules (so we have not observed the additions to come for these rules) or because there is a life cycle in a regulatory program such that the controversial RCRA rules (supplemented by informal rules) have been issued earlier on and the formal rules in the later stages of the program are more clarifying than controversial. A revision of RCRA legislation, however, could start another new cycle of informal rules.

Table 9 focuses on a different question: for those rules which are supplemented by informal rules, what factors influence the length of the OSWER documents? The regression sample here is the 210 formal decimal point CFR rules that are cross-referenced with OSWER directives, with the dependent variable being the number of pages of policy memos, guidance manuals, and directives associated with the formal rule. Again, the signs and statistical significance of the variables are similar across the different specifications of the model, so we focus on specification (4), the fullest specification. Those rules that require the facility to provide new information, those associated with technology standards requiring expenditures on human or physical capital, and those relating to cleanups at contaminated hazardous waste facilities (for example, RCRA corrective actions) are likely to be longer rules. The details involved in technology standards and descriptions of cleanup standards and technologies thus make the informal rules associated with these requirements longer. Rules covering technologies that are subject to failures such as groundwater contamination, including waste piles, surface impoundments, and landfills, are also substantially longer. Finally, those rules that have been the subject of court remands are also likely to be associated with more pages of OSWER directives, consistent with the hypothesis that the agency attempts to circumvent judicial action by issuing more informal requirements.

Table 10 provides additional evidence for the assessment that the Hotline responses are not generated by the same agency process as the informal rules such as the OSWER directives. The results in specification (4) are consistent with an interpretation of the Hotline responses as representing agency answers to frequently-asked questions from the regulated community. In terms of types of rules, nearly all types of rules are less likely to generate questions than the omitted rule classification-rules setting forth definitions. Rules relating to generators are more likely to be associated with Hotline responses, which may be explained in part by the large number of facilities that are generators regulated under RCRA. More costly rules, denoted by the major rule variable, are also more likely to generate questions answered through the Hotline. An additional variable included in this specification indicates whether there are OSWER documents associated with the formal rule. The positive and statistically significant coefficient may indicate that the underlying variables that lead to the issuance of the OSWER document may also lead to Hotline questions. Yet since we have attempted to control for these in the regression, the result can also be interpreted as indicating that CFR regulations with 
informal rules are associated with more questions from the regulated community. One complaint about informal rules from the regulated community is that they create uncertain property rights and are more difficult to understand; the positive association between OSWER documents and Hotline questions may reflect the uncertainty associated with informal rules.

The data collected for the analysis of rulemaking also allow us to make some observations about the determinants of court remands. Note that we lack information on the timing of the actions taken by Congress and the courts and when the OSWER documents were issued, and that our variables code whether any version of a rule was subject to a particular type of scrutiny. Thus, we cannot know with certainty for a formal rule that has both a hammer provision and court remand whether the hammer provision came before the court remand or whether the court remand pre-dated the version of the rule that was later the subject of the hammer provision. Yet, assuming that congressional action predates the agency or court actions here, we can derive some lessons from the logistic analysis in Table 11 of what types of rules are the subject of court remands and consent decrees.

In terms of types of rules, requirements relating to testing and technical standards relating to human and physical capital were less likely to be the subject of court remands, perhaps indicating either a willingness by courts to let agency actions stand in this area or a lower frequency of challenge. In areas where the agency may attempt to exercise more discretion in terms of its actions, such as enforcement actions and closure requirements, court remands were more likely. Rules with hammer provisions were less likely to be remanded by the courts or to be the subject of consent decrees, which would be consistent with courts' willingness to let these provisions stand because of congressional specificity or because of a lower frequency of challenge. Rules that were revised often, an indicator of controversy, were also more likely to be the subject of remand, while, other things being equal, rules imposing larger costs were less likely. This may be because formal rules designated as major because of their costs are shown deference by courts willing to accept agency decisions on these rules, which have undergone extensive examination (a regulatory impact analysis) during the rulemaking stage. Finally, those rules with associated informal rules in the form of OSWER documents were more likely to be the subject of court remands, which may indicate that attempts to apply informal rules or exercise agency discretion beyond that provided for in formal standards may lead to court remands or consent decrees.

\section{IV}

\section{CONCLUSION}

Previous models of the political economy of administrative law have focused on how the requirements of formal rulemaking, such as the notice-and-comment process, serve as a constraint on agency behavior. Congress is viewed as using the design of the rulemaking environment to facilitate channeling and monitor- 
ing, allowing interest groups to shape the final rules that emerge, and to alert members of Congress to agency actions that may require oversight and reversal. This article argues that regulators should also be viewed as strategic in choosing administrative processes. More precisely, we assert that an agency desiring to issue a rule faces decisions about both the content of the rule and the format of its enunciation. We have termed "informal rules" those rules that are issued outside of the traditional APA paradigm of Federal Register notice-and-comment procedure.

The existence of informal rules at first may appear unlikely, for why would regulated parties adhere to rules that might easily be challenged as having been adopted improperly? In an arena where procedural challenges often mark broader struggles over substantive policy differences, why would environmentalists or industry participants allow informal rules to go unchallenged? We believe part of the answer lies in the fact that in a program such as the regulation of hazardous waste under RCRA, the process of negotiations that surrounds the permitting process and the prospect of multiple future interactions between regulators and permit holders means that the informal rules may be used to establish agency bargaining positions. The regulated parties technically might not have to meet all the requirements in these rules, and, in fact, one reason the EPA may prefer informality is that it allows regulators leeway, too. Still, the discretion embodied in the permitting process may provide the regulators with leverage to secure adherence to rules that have not been formally promulgated. Thus, while some parties may challenge these rules, and our data provides some evidence that rules that have informal components are more likely to be the subject of court remands, these informal rules do provide the agency with a way to promote requirements without using the "political market" to secure agreement on formal rules.

An alternative explanation for the over 19,500 pages of OSWER documents is that they are simply clarifications that spell out the requirements of the formally published rules. If this were the case, however, there would be few differences between those CFR rules with and without OSWER documents, except perhaps in terms of which rules were more technical and thus required elaboration. We have presented hypotheses about why the agency may strategically choose to issue requirements informally and tested these with data from the rules implementing RCRA. Our results are consistent with a strategic agency that chooses informality when it wishes to provide for greater discretion in agency actions, to establish rules that entail major costs, to promote standards that involve controversy, to provide for individual negotiations over issues that involve smaller numbers of facilities, and to avoid congressional and judicial scrutiny and constraints as signaled by actions such as court remands.

Informality thus offers a means for regulators to evade both the constraints imposed by Congress and the courts and the executive branch oversight exercised by OMB. We do not claim that these informal rules go unnoticed by the legislative and judicial branches, just as slack does not go unnoticed in general principal-agent relationships. Rather, courts and Congress must weigh the costs 
of monitoring and punishing agencies against the costs posed by agency discretion embodied in informal rules. This view does not mean that the ability to issue informal rules frees agencies from congressional constraints. It means rather that just as members of Congress face strategic decisions about the form of administrative procedures, regulators face strategic decisions about the degree to which they comply with the formal requirements of rulemaking in establishing the "rules" that define property rights for the regulated community. 


\section{APPENDIX}

\section{TABLE 1}

\section{VARIAble DefintTIONS}

Variable

Rule Requirements: Variable $=1$ if the rule

Existing Information

New Information

Testing

Technical Standard

Enforcement

Financial

Closure

Corrective Action
Definition

INFOEXST Requires provision of existing information

INFONEW Requires provision of new information

TEST Requires testing or monitoring at the site

TECHSTAN Requires expenditure on specific physical or human capital

ENF Relates to enforcement actions or inspections

FIN Relates to financial requirements

CLOSE Deals with closure or post-closure issues

CORACT Deals with corrective action (i.e. cleanup) provisions

DEFN Establishes applicability requirement (i.e. defines words or the scope of coverage)

Specific Technologies: Variable $=1$ if the rule covers the specific technology of

Containers

Tanks

Piles

Impoundments

Incinerators

Landfills

Land Treatment

Other Technology
CONTAIN

TANK

PILE

SURIM

INCIN

LNDFILL

LNDTRT

MISC
Container storage

Tanks

Waste piles

Surface impoundments

Incinerators

Landfills

Land treatment

Other technologies, including drip pads

Rule History: Variable $=1$ for the rule if for any version of the rule, past or current,

Hammer

Deadline

Court Deadline

Court Remand

Major Rule

Other variables:

Technical Corrections

Total Versions

Generators

Commercial Facilities

"Informal" variables:

OSWERs

Total OSWERs

Total OSWER Pages

RDBs

Total RDBs

Total RDB Pages

Hotline Responses

Total HOT Responses
HAMT

DEADT

CRTIMPT Courts imposed a deadline for rule issuance

Congress set a deadline with a fallback position if the agency did not act Congress set a deadline for rule issuance but did not specify a fallback position

CRTREMT Courts remanded a rule to the agency or the version of the rule arose from court actions (including consent decrees)

MAJORT Rule was designated as a "major rule"

TCHCORN Number of revisions to the rule that were technical corrections

VERTOT Total number of revisions to the rule

GENFAC $\quad=1$ if the rule applies specifically to waste generators

COMFAC $=1$ if rule applies specifically to commercial waste handling facilities

OSYES $\quad=1$ if there are OSWER directives relating to this rule

OSCNT Number of OSWER directives

OSPGTOT Number of pages of OSWER directives

RDYES $=1$ if there are RDB memos relating to this rule

RDCNT Number of RDB memos

RDPGTOT Number of pages of RDB memos

HOT $=1$ if there are Hotline responses relating to this rule

HOTTOT Total number of Hotline responses 
TABLE 2

Expected Coefficient Signs in the Model Predicting Whether OSWER Directives Supplement a Formal Rule

\begin{tabular}{lcccccc} 
& Transaction & Political & \multicolumn{2}{c}{ Hypotheses } \\
Vegulatory & Application/ & Congressional & Judicial \\
Variables & Costs & Costs & Costs & Enforcement & Scrutiny & Scrutiny \\
\hline
\end{tabular}

Rule Requirements

Existing Information

New Information

Testing

Technical Standards

Enforcement

Financial

Closure

Corrective Actions

Definition

Specific Technologies

Containers

Tanks

Piles

Impoundments

Incinerators

Landfills

Land Treatment

Other Technologies

Rule History

Hammer

Deadline

Court Deadline

Court Remand

Major Rule

Other Variables

Technical Corrections

Total Versions

Generators

Commercial Facilities

$\begin{array}{lll}+ & + \\ + & + \\ + & + & + \\ + & +\end{array}$

$\begin{array}{ll}- & \\ + & \\ + & \\ + & + \\ + & + \\ + & \end{array}$

Note: $A+$ indicates that for a given hypothesis a formal rule will be more likely to be supplemented by an OSWER directive, while a - indicates it will be less likely to be supplemented by an OSWER directive. 
TABLE 3

Hazardous Waste Management Technologies

Management Method

Quantity Managed in 1986

Metal Recovery

Solvent recovery

Other recycling

Fuel blending

(Million Tons)

Number of Facilities

Reuse as fuel

Incineration

Solidification

\subsection{4}

1.18

330

Land treatment

0.96

0.75

1.44

1.09

0.77

0.38

Wastewater treatment

Disposal impoundment

732.00

4.61

232.00

Surface impoundment

3.17

0.68

Waste pile

28.7

189.00

1470

1470
243

177

295

197

122

58

4399

70

Underground injection

$\begin{array}{r}1.98 \\ \hline\end{array}$

298

118

71

63

1785

Other treatment

128

Note: Quantities reported were obtained using the 1986 EPA TSDR survey. Total waste generated in 1986 was 747 million tons; note that some wastes were managed in multiple treatment technologies and that wastes can be sent to and removed from storage. Disposal impoundments are surface impoundments used for disposing of hazardous waste. Surface impoundment figures include waste entering surface impoundments for disposal, treatment, and storage.

Source: This table is reproduced from Baker et.al., 1992. 
TABLE 4

\section{Number of Rule Enunciations Per Year, By Type of Rule}

\begin{tabular}{|c|c|c|c|c|}
\hline \multirow[b]{2}{*}{ Year } & \multicolumn{2}{|c|}{ New Formal Rules } & \multicolumn{2}{|c|}{ Total Formal Rules } \\
\hline & Number & Percent & Number & Percent \\
\hline $\begin{array}{l}1980 \\
1981 \\
1982 \\
1983 \\
1984 \\
1985 \\
1986 \\
1987 \\
1988 \\
1989 \\
1990 \\
1991 \\
\text { Total: }\end{array}$ & $\begin{array}{r}153 \\
30 \\
72 \\
75 \\
3 \\
44 \\
80 \\
12 \\
107 \\
19 \\
74 \\
28 \\
697\end{array}$ & $\begin{array}{r}22.0 \\
4.3 \\
10.3 \\
10.8 \\
.4 \\
6.3 \\
11.5 \\
1.7 \\
15.4 \\
2.7 \\
10.6 \\
4.0\end{array}$ & $\begin{array}{r}175 \\
53 \\
109 \\
150 \\
21 \\
196 \\
211 \\
85 \\
190 \\
94 \\
185 \\
165 \\
1634\end{array}$ & $\begin{array}{r}10.7 \\
3.2 \\
6.7 \\
9.2 \\
1.3 \\
12.0 \\
12.9 \\
5.2 \\
11.6 \\
5.8 \\
11.3 \\
10.1\end{array}$ \\
\hline & \multicolumn{2}{|c|}{ OSWER Directives } & \multirow{2}{*}{\multicolumn{2}{|c|}{ OSWER Directive Page Totals }} \\
\hline Year & Number & Percent & & Percent \\
\hline $\begin{array}{l}1980 \\
1981 \\
1982 \\
1983 \\
1984 \\
1985 \\
1986 \\
1987 \\
1988 \\
1989 \\
1990 \\
1991 \\
\text { Total: }\end{array}$ & $\begin{array}{r}20 \\
17 \\
26 \\
36 \\
124 \\
121 \\
69 \\
32 \\
28 \\
16 \\
11 \\
5 \\
505\end{array}$ & $\begin{array}{r}4.0 \\
3.4 \\
5.1 \\
7.1 \\
24.6 \\
24.0 \\
13.7 \\
6.3 \\
5.5 \\
3.2 \\
2.2 \\
1.0\end{array}$ & $\begin{array}{r}99 \\
586 \\
1542 \\
1372 \\
2201 \\
2336 \\
4850 \\
805 \\
1850 \\
1958 \\
1383 \\
554 \\
19,536\end{array}$ & $\begin{array}{r}.51 \\
3.00 \\
7.89 \\
7.02 \\
11.27 \\
11.96 \\
24.83 \\
4.12 \\
9.47 \\
10.02 \\
7.08 \\
2.84\end{array}$ \\
\hline Year & \multicolumn{2}{|c|}{ RDB Memos } & \multicolumn{2}{|c|}{ RDB Page Totals } \\
\hline $\begin{array}{l}1980 \\
1981 \\
1982 \\
1983 \\
1984 \\
1985 \\
1986 \\
1987 \\
1988 \\
1989 \\
1990 \\
1991 \\
\text { Total: }\end{array}$ & $\begin{array}{r}0 \\
0 \\
0 \\
1 \\
3 \\
50 \\
81 \\
92 \\
58 \\
49 \\
25 \\
10 \\
369\end{array}$ & $\begin{array}{r}0 \\
0 \\
0 \\
0 \\
.3 \\
.8 \\
13.6 \\
22.0 \\
24.9 \\
15.7 \\
13.3 \\
6.8 \\
2.7\end{array}$ & $\begin{array}{r}0 \\
0 \\
0 \\
1 \\
7 \\
145 \\
273 \\
357 \\
216 \\
130 \\
76 \\
24 \\
1229\end{array}$ & $\begin{array}{c}0 \\
0 \\
0 \\
0 \\
.08 \\
.57 \\
11.80 \\
22.21 \\
29.05 \\
17.58 \\
14.99 \\
6.18 \\
1.95\end{array}$ \\
\hline Year & Number & Percent & & \\
\hline $\begin{array}{l}1980 \\
1981 \\
1982 \\
1983 \\
1984 \\
1985 \\
1986 \\
1987 \\
1988 \\
1989 \\
1990 \\
1991 \\
\text { Total: }\end{array}$ & $\begin{array}{r}0 \\
0 \\
0 \\
0 \\
0 \\
30 \\
62 \\
48 \\
46 \\
44 \\
20 \\
12 \\
262\end{array}$ & $\begin{array}{c}0 \\
0 \\
0 \\
0 \\
0 \\
11.5 \\
23.7 \\
18.3 \\
17.3 \\
16.8 \\
7.6 \\
4.6\end{array}$ & & \\
\hline
\end{tabular}


TABLE 5

Variable Percentages and Means by Subsample

\begin{tabular}{|c|c|c|c|c|c|c|c|}
\hline Variables: Percentages & $\begin{array}{c}\text { Full } \\
\text { Sample }\end{array}$ & $\begin{array}{c}\text { Rules } \\
\text { with } \\
\text { OSWER }\end{array}$ & $\begin{array}{c}\text { Rules } \\
\text { without } \\
\text { OSWER }\end{array}$ & $\begin{array}{c}\text { Rules } \\
\text { with } \\
\text { RDB }\end{array}$ & $\begin{array}{c}\text { Rules } \\
\text { without } \\
\text { RBD }\end{array}$ & $\begin{array}{c}\text { Rules } \\
\text { with } \\
\text { Hotline }\end{array}$ & $\begin{array}{l}\text { Rules } \\
\text { without } \\
\text { Hotline }\end{array}$ \\
\hline Existing Information & $5.2 \%$ & $4.8 \%$ & $5.3 \%$ & $8.5 \%$ & $4.9 \%$ & $5.4 \%$ & $5.1 \%$ \\
\hline New Information & 25.8 & 29.5 & 24.2 & 23.4 & 26.0 & 22.8 & 26.6 \\
\hline Testing & 10.5 & 7.6 & 11.7 & 0 & 11.2 & 7.4 & 11.3 \\
\hline Technical Standard & 32.0 & 23.3 & 35.7 & 14.9 & 33.2 & 24.8 & 33.9 \\
\hline Enforcement & 21.1 & 31.9 & 16.4 & 10.6 & 21.8 & 15.4 & 22.6 \\
\hline Financial & 6.2 & 6.2 & 6.2 & 0 & 6.6 & 6.7 & 6.0 \\
\hline Closure & 7.9 & 14.8 & 4.9 & 0 & 8.5 & 14.1 & 6.2 \\
\hline Corrective Action & 1.4 & 1.0 & 1.6 & 0 & 1.5 & 1.3 & 1.5 \\
\hline Definition & 19.1 & 20.0 & 18.7 & 59.6 & 16.2 & 34.2 & 15.0 \\
\hline Containers & 3.4 & 1.4 & 4.3 & 2.1 & 3.5 & 2.7 & 3.6 \\
\hline Tanks & 15.4 & 8.1 & 18.5 & 0 & 16.5 & 18.8 & 14.4 \\
\hline Piles & 2.4 & 2.9 & 2.3 & 0 & 2.6 & 2.0 & 2.6 \\
\hline Impoundments & 2.9 & 3.3 & 2.7 & 0 & 3.1 & 3.4 & 2.7 \\
\hline Incinerators & 2.3 & 3.8 & 1.6 & 0 & 2.5 & 1.3 & 2.6 \\
\hline Landfills & 3.4 & 5.7 & 2.5 & 0 & 3.7 & 4.7 & 3.1 \\
\hline Land Treatment & 3.2 & 3.8 & 2.9 & 0 & 3.4 & 6.7 & 3.8 \\
\hline Other Technology & 2.3 & .5 & 3.1 & 0 & 2.5 & 0 & 2.9 \\
\hline Hammer & 13.2 & 16.7 & 11.7 & 44.7 & 10.9 & 28.2 & 9.1 \\
\hline Deadline & 10.0 & 11.0 & 9.7 & 10.6 & 10.0 & 16.1 & 8.4 \\
\hline Court Deadline & 9.8 & 17.6 & 6.4 & 8.5 & 9.8 & 14.1 & 8.6 \\
\hline Court Remand & 21.8 & 46.7 & 11.1 & 23.4 & 21.7 & 30.2 & 19.5 \\
\hline Major Rule & 31.3 & 42.9 & 26.3 & 48.9 & 30.0 & 53.7 & 25.2 \\
\hline Generators & 5.2 & 5.7 & 4.9 & 42.6 & 2.5 & 8.7 & 4.2 \\
\hline Commercial Facilities & 1.1 & 0 & 1.6 & 0 & 1.2 & 1.3 & 1.1 \\
\hline OSWERs & 30.1 & 100.0 & 0 & 59.6 & 28.0 & 61.1 & 21.7 \\
\hline RDBs & 6.7 & 13.3 & 3.9 & 100.0 & 0 & 20.1 & 3.1 \\
\hline Hotline Responses & 21.4 & 43.3 & 11.9 & 63.8 & 18.3 & 100.0 & 0 \\
\hline \multicolumn{8}{|c|}{ Variables: Average Number } \\
\hline Technical Corrections & .42 & .32 & .63 & 1.1 & .36 & .74 & .32 \\
\hline Total Versions & 2.3 & 3.6 & 1.8 & 5.3 & 2.1 & 3.9 & 1.9 \\
\hline Total OSWERs & 1.4 & 4.6 & 0 & 5.4 & 1.1 & 4.4 & .54 \\
\hline Total OSWER Pages & 56.4 & 187 & 0 & 51.2 & 56.7 & 153.5 & 29.9 \\
\hline Total RDBs & .91 & 2.6 & .19 & 13.5 & 0 & 3.9 & .10 \\
\hline Total RDB Pages & 3.2 & 9.2 & .54 & 46.8 & 0 & 13.7 & .29 \\
\hline Total Hotline Responses & .69 & 1.7 & .24 & 4.0 & .45 & 3.2 & 0 \\
\hline
\end{tabular}

Note: The full sample consisted of 697 formal rules. Of these, 210 had OSWER directives, 47 had RDBs, and 149 had Hotline responses. 
TABle 6

Correlations of Selected Regression Variables

Court Remand

Hammer

Court Deadline $\quad 0.057$

Court Remand $\quad-0.042$

Major Rule

OSWERs

$0.377^{*}$

0.067

Deadine

Court Deadline

RDBs

$0.250^{*}$

$0.282^{*}$

0.003
0.008
0.001
0.020
0.005
0.215

$-0.010$

$0.467 *$

$0.174^{*}$

$-0.101 *$

Total Hotline Responses

$0.215^{*}$

$-0.011$

$0.395^{*}$

Major Rule

OSWERS

RDBs

Total Hotline Responses

Hammer

Deadline

Court Deadline

Court Remand

Major Rule

OSWERs

$0.164^{*}$

RDBs 0.102 *

Total Hotline Responses

$0.197^{*}$

$0.173^{*}$

$0.309^{*}$

$0.404^{*}$

Note: $*$ = statistically significant at the $1 \%$ level; $* *=$ statistically significant at the $5 \%$ level. 
TABLE 7

OSWER DiRectives by Year and Category Requirements

\begin{tabular}{|c|c|c|c|c|c|c|c|c|}
\hline \multirow[b]{2}{*}{ Year } & \multicolumn{2}{|c|}{$\begin{array}{l}\text { Existing } \\
\text { Information }\end{array}$} & \multicolumn{2}{|c|}{ New Information } & \multicolumn{2}{|c|}{ Testing } & \multicolumn{2}{|c|}{$\begin{array}{l}\text { Technical } \\
\text { Standards }\end{array}$} \\
\hline & Count & $\%$ & Count & $\%$ & Count & $\%$ & Count & $\%$ \\
\hline 1980 & 4 & 11 & 1 & .4 & $\mathbf{0}$ & 0 & 2 & 1 \\
\hline 1981 & 5 & 13 & 5 & 2 & 0 & 0 & 4 & 2 \\
\hline 1982 & 1 & 3 & 14 & 5 & 1 & 3 & 7 & 3 \\
\hline 1983 & 4 & 11 & 19 & 7 & 10 & 26 & 16 & 8 \\
\hline 1984 & 4 & 11 & 57 & 22 & 9 & 23 & 25 & 12 \\
\hline 1985 & 9 & 24 & 41 & 16 & 3 & 8 & 55 & 26 \\
\hline 1986 & 4 & 11 & 59 & 23 & 8 & 21 & 46 & 22 \\
\hline 1987 & 5 & 13 & 21 & 8 & 2 & 5 & 14 & 7 \\
\hline 1988 & 2 & 5 & 26 & 10 & 6 & 15 & 34 & 16 \\
\hline 1989 & 0 & 0 & 8 & 3 & 0 & 0 & 4 & 2 \\
\hline 1990 & 0 & $\mathbf{0}$ & 3 & 1 & $\mathbf{0}$ & 0 & 3 & 1 \\
\hline 1991 & 0 & $\mathbf{0}$ & 1 & .4 & $\mathbf{0}$ & 0 & 0 & 0 \\
\hline \multirow[t]{2}{*}{ Total: } & 38 & & 255 & & 39 & & 210 & \\
\hline & \multicolumn{2}{|c|}{ Financial } & \multicolumn{2}{|c|}{ Closure } & \multicolumn{2}{|c|}{ Enforcement } & \multicolumn{2}{|c|}{ Corrective Actior } \\
\hline Year & Count & $\%$ & Count & $\%$ & Count & $\%$ & Count & $\%$ \\
\hline 1980 & 0 & 0 & 0 & 0 & 0 & 0 & $\mathbf{0}$ & 0 \\
\hline 1981 & 0 & 0 & 0 & 0 & 10 & 3 & 0 & 0 \\
\hline 1982 & 7 & 14 & 11 & 11 & 24 & 8 & $\mathbf{0}$ & 0 \\
\hline 1983 & 4 & 8 & 9 & 9 & 32 & 11 & 0 & 0 \\
\hline 1984 & 12 & 24 & 16 & 16 & 71 & 23 & 1 & 4 \\
\hline 1985 & 0 & 0 & 3 & 3 & 58 & 19 & 5 & 19 \\
\hline 1986 & 16 & 32 & 24 & 23 & 54 & 18 & 10 & 37 \\
\hline 1987 & 11 & 22 & 11 & 11 & 21 & 7 & 4 & 15 \\
\hline 1988 & 0 & 0 & 26 & 25 & 18 & 6 & 4 & 15 \\
\hline 1989 & 0 & 0 & 3 & 3 & 15 & 5 & 2 & 7 \\
\hline 1990 & 0 & 0 & 0 & 0 & 4 & 1 & 0 & 0 \\
\hline 1991 & 0 & 0 & 0 & 0 & 1 & .3 & 1 & 4 \\
\hline Total: & 50 & & 103 & & 308 & & 27 & \\
\hline
\end{tabular}

\begin{tabular}{rrrrrrrrr} 
& \multicolumn{2}{c}{$\begin{array}{c}\text { Definition } \\
\text { Year }\end{array}$} & Count & $\%$ & Containers & \multicolumn{2}{c}{ Tanks } & \multicolumn{2}{c}{ Piles } \\
1980 & 17 & 5 & 1 & 4 & 0 & 0 & 0 & 0 \\
1981 & 14 & 4 & 0 & 0 & 0 & 0 & 0 & 0 \\
1982 & 11 & 3 & 0 & 0 & 0 & 0 & 0 & 0 \\
1983 & 27 & 8 & 1 & 4 & 0 & 0 & 2 & 8 \\
1984 & 101 & 31 & 5 & 21 & 0 & 0 & 2 & 8 \\
1985 & 90 & 28 & 11 & 46 & 3 & 9 & 8 & 31 \\
1986 & 26 & 8 & 4 & 17 & 10 & 30 & 8 & 31 \\
1987 & 12 & 4 & 0 & 0 & 0 & 0 & 1 & 4 \\
1988 & 12 & 4 & 2 & 8 & 12 & 36 & 4 & 15 \\
1989 & 8 & 2 & 0 & 0 & 7 & 21 & 1 & 4 \\
1990 & 12 & 4 & 0 & 0 & 1 & 3 & 0 & 0 \\
1991 & 12 & 4 & 0 & 0 & 0 & 0 & 0 & 0 \\
Total & 322 & & 24 & & 33 & & 26 &
\end{tabular}




\begin{tabular}{ccc} 
& \multicolumn{2}{c}{ Impoundments } \\
Year & Count & $\%$ \\
1980 & 0 & 0 \\
1981 & 0 & 0 \\
1982 & 4 & 8 \\
1983 & 4 & 8 \\
1984 & 2 & 4 \\
1985 & 12 & 24 \\
1986 & 12 & 24 \\
1987 & 4 & 8 \\
1988 & 11 & 22 \\
1989 & 2 & 4 \\
1990 & 0 & 0 \\
1991 & 0 & 0 \\
Total: & 51 &
\end{tabular}

\begin{tabular}{cr}
\multicolumn{2}{c}{ Incinerators } \\
Count & $\%$ \\
0 & 0 \\
1 & 3 \\
3 & 8 \\
5 & 13 \\
5 & 13 \\
5 & 13 \\
14 & 37 \\
0 & 0 \\
3 & 8 \\
2 & 5 \\
0 & 0 \\
0 & 0 \\
24 &
\end{tabular}

\begin{tabular}{cr}
\multicolumn{2}{c}{ Landfills } \\
Count & $\%$ \\
0 & 0 \\
0 & 0 \\
4 & 5 \\
6 & 8 \\
11 & 14 \\
23 & 30 \\
16 & 21 \\
2 & 3 \\
12 & 16 \\
2 & 3 \\
0 & 0 \\
0 & 0 \\
76 &
\end{tabular}

\begin{tabular}{rr}
\multicolumn{2}{c}{ Land Treatment } \\
Count & $\%$ \\
0 & 0 \\
0 & 0 \\
0 & 0 \\
6 & 22 \\
11 & 41 \\
0 & 0 \\
5 & 19 \\
1 & 4 \\
3 & 11 \\
1 & 4 \\
0 & 0 \\
0 & 0 \\
27 &
\end{tabular}

\begin{tabular}{ccr} 
& \multicolumn{2}{c}{ Deadline } \\
Year & Count & $\%$ \\
1980 & 4 & 3 \\
1981 & 2 & 1 \\
1982 & 4 & 3 \\
1983 & 16 & 10 \\
1984 & 48 & 30 \\
1985 & 43 & 27 \\
1986 & 17 & 11 \\
1987 & 11 & 7 \\
1988 & 10 & 6 \\
1989 & 2 & 1 \\
1990 & 1 & 1 \\
1991 & 1 & 1 \\
Total: & 159 &
\end{tabular}

\begin{tabular}{cc}
\multicolumn{2}{c}{ Court Deadline } \\
Count & $\%$ \\
5 & 2 \\
4 & 2 \\
7 & 3 \\
25 & 9 \\
72 & 27 \\
59 & 22 \\
40 & 15 \\
22 & 8 \\
25 & 9 \\
6 & 2 \\
0 & 0 \\
1 & .4 \\
266 &
\end{tabular}

\section{Court Remand}

Count \%

\section{Major Rule}

Count \%

\begin{tabular}{rr}
4 & 2 \\
5 & 2 \\
10 & 5 \\
19 & 9 \\
59 & 28 \\
40 & 19 \\
28 & 13 \\
24 & 11 \\
17 & 8 \\
4 & 2 \\
0 & 0 \\
1 & \multicolumn{2}{c}{.5} \\
211 &
\end{tabular}

$\begin{array}{rr}6 & 1 \\ 17 & 3 \\ 32 & 6 \\ 56 & 10 \\ 130 & 24 \\ 105 & 19 \\ 94 & 17 \\ 45 & 8 \\ 40 & 7 \\ 12 & 2 \\ 1 & .2 \\ 2 & .4 \\ 540 & \end{array}$

\begin{tabular}{lcrcr} 
& \multicolumn{2}{c}{ Generators } & \multicolumn{2}{c}{ Hammer } \\
Year & Count & $\%$ & Count & $\%$ \\
1980 & 3 & 10 & 13 & 5 \\
1981 & 4 & 13 & 13 & 5 \\
1982 & 2 & 7 & 11 & 4 \\
1983 & 0 & 0 & 29 & 10 \\
1984 & 5 & 17 & 87 & 30 \\
1985 & 10 & 33 & 75 & 26 \\
1986 & 4 & 13 & 31 & 11 \\
1987 & 1 & 3 & 13 & 5 \\
1988 & 0 & 0 & 5 & 2 \\
1989 & 1 & 3 & 5 & 2 \\
1990 & 0 & 0 & 5 & 2 \\
1991 & 0 & 0 & 1 & .4 \\
Total: & 30 & & 288 &
\end{tabular}

Note: The unit of analysis is the regulatory requirement in an OSWER directive, obtained by matching each OSWER directive with the characteristics of the CFR rule(s) associated with it. Counts represent the number of OSWER requirements issued in a given year associated with the particular category, based on counts of the characteristics of the CFR rules matched with the OSWER directives. A single OSWER directive may be counted in more than one category if it deals with multiple categories or is referenced by more than one CFR rule. There are a total of 961 pairings of CFR rules and OSWER directives categorized here. 
TABLE 8

\section{Determinants of Informal Rulemaking: Logistic Regressions Predicting Whether OSWER Documents SupPlement the Formal Rule}

(1)

Parameter Parameter

estimate S.E. estimate

$\begin{array}{lll}-1.044 & (0.175) & -0.992\end{array}$

Intercept

$0.005 \quad(0.406) \quad-0.102$

$0.104 \quad(0.203) \quad 0.092$

$-0.209 \quad(0.314)-0.177$

$\begin{array}{llll}(0.314) & -0.177 & (0.323) & 0.011\end{array}$

Testing

Technical Standards

Financial

Enforcement

$\begin{array}{llllr}-0.369 * * & (0.220) & -0.421 * * & (0.231) & -0.247 \\ -0.305 & (0.377) & 0.039 & (0.411) & 0.115\end{array}$

$0.839 *$

$0.859 *(0.228)$

$1.425^{*}(0.314) \quad 0.981^{*}$

$\begin{array}{lll}0.187 & (0.839) & 0.391\end{array}$

$-1.209^{* *}(0.671)-1.242^{* *}$

Corrective Action

$-0.465$

(0.808)

Containers

Tanks

Piles

Impoundments

Incinerators

Landfills

Land Treatment

Other Technologies

Generators

Deadline

Hammer

Court Deadline

Court Remand

Total Versions

Major Rule

1981

1982

1983

1984

1985

1986

1987

1988

1989

1990-91

Log likelihood

Number of

Observations
(3)

(4)

(5)

Parameter Parameter 
TABLE 9

Determinants of Length of INFORMal Rules: OLS Regressions Predicting Number of OSWER Document Pages for Formal Rules Supplemented by OSWER DIRECTIVES

(1)

(2)

(3)

(4)

\begin{tabular}{|c|c|c|c|c|c|c|c|c|}
\hline & $\begin{array}{l}\text { Parameter } \\
\text { estimate }\end{array}$ & S.E. & $\begin{array}{l}\text { Parameter } \\
\text { estimate }\end{array}$ & S.E. & $\begin{array}{l}\text { Parameter } \\
\text { estimate }\end{array}$ & S.E. & $\begin{array}{l}\text { Parameter } \\
\text { estimate }\end{array}$ & S.E. \\
\hline Intercept & 48.31 & $(60.72)$ & 53.2 & $(64.19)$ & -33.21 & $(77.99)$ & -71.52 & (84.33) \\
\hline Existing Information & -81.58 & (141.53) & -47.11 & (139.11) & -68.60 & (139.06) & -61.48 & (139.95) \\
\hline New Information & $141.82^{*}$ & $(67.95)$ & $148.69 *$ & $(67.81)$ & $136.17^{*}$ & $(68.90)$ & $140.19 *$ & $(69.13)$ \\
\hline Testing & 9.20 & (118.64) & -70.11 & (118.97) & -85.57 & (119.94) & -69.66 & (120.93) \\
\hline Technical Standards & $216.59^{*}$ & $(79.02)$ & $165.81^{*}$ & $(81.89)$ & $178.67^{*}$ & $(83.35)$ & $188.95^{*}$ & (84.30) \\
\hline Financial & 163.99 & (134.55) & 195.68 & (134.41) & 200.38 & (134.91) & 191.12 & (136.58) \\
\hline Enforcement & 112.85 & $(71.94)$ & 102.31 & $(73.66)$ & 88.53 & (77.75) & 95.53 & (78.10) \\
\hline Closure & -19.46 & $(90.76)$ & -84.91 & (90.57) & -122.09 & (93.32) & -95.83 & (95.87) \\
\hline Corrective Action & $652.78^{*}$ & (308.79) & $644.45^{*}$ & (301.19) & 703.44* & (302.42) & $685.91^{*}$ & (305.14) \\
\hline Containers & & & -187.86 & (258.81) & -216.08 & (257.13) & -226.94 & $(257.64)$ \\
\hline Tanks & & & -82.71 & (110.63) & -64.6 & (122.38) & -47.85 & (123.91) \\
\hline Piles & & & $407.54^{*}$ & (177.82) & $439.0^{*}$ & (184.61) & $422.98^{*}$ & (188.61) \\
\hline Impoundments & & & $447.00^{*}$ & (163.88) & $472.31 *$ & (164.69) & $457.39^{*}$ & (166.88) \\
\hline Incinerators & & & -71.56 & (156.57) & -81.76 & (156.36) & -72.37 & (158.17) \\
\hline Landfills & & & $233.18^{* *}$ & (136.94) & $256.16^{* *}$ & (146.21) & $261.65^{* *}$ & (147.57) \\
\hline Land Treatment & & & 79.11 & (154.24) & 91.37 & (160.56) & 101.53 & (161.79) \\
\hline Other Technologies & & & -31.2 & (422.29) & 55.21 & (420.12) & 84.75 & (421.55) \\
\hline Generators & & & -177.80 & (129.76) & -160.57 & (130.14) & -165.11 & (130.36) \\
\hline Deadline & & & & & 151.29 & (111.12) & 113.92 & (120.98) \\
\hline Hammer & & & & & -0.5 & $(90.26)$ & -70.03 & (107.24) \\
\hline Court Deadline & & & & & 67.36 & (93.76) & 6.21 & (106.91) \\
\hline Court Remand & & & & & $137.99^{*}$ & $(66.80)$ & $126.77^{*}$ & $(68.98)$ \\
\hline Total Versions & & & & & & & 8.77 & $(9.46)$ \\
\hline Major Rule & & & & & & & 62.49 & (81.56) \\
\hline Adj. $R^{2}$ & \multicolumn{2}{|c|}{.04} & \multicolumn{2}{|c|}{.08} & \multicolumn{2}{|c|}{.10} & \multicolumn{2}{|c|}{.10} \\
\hline $\begin{array}{l}\text { Number of } \\
\text { Observations }\end{array}$ & \multicolumn{2}{|c|}{210} & \multicolumn{2}{|c|}{210} & \multicolumn{2}{|c|}{210} & \multicolumn{2}{|c|}{210} \\
\hline
\end{tabular}

$*$ = statistically significant at $5 \%$ level; $* *=$ statistically significant at the $10 \%$ level.

Note: Sample consists of formal rules implementing RCRA which had OSWER directives associated with them. Dependent variable in OLS regression is the number of pages of OSWER documents associated with the rule. Standard errors are in parentheses. 
TABLE 10

Determinants of Hotline Responses: Logistic Regressions Predicting Whether the Rule Was Covered by a Hotline Response

(1)

(2)

(3)

(4)

\begin{tabular}{|c|c|c|c|c|c|c|c|c|}
\hline & $\begin{array}{l}\text { Parameter } \\
\text { estimate }\end{array}$ & S.E. & $\begin{array}{l}\text { Parameter } \\
\text { estimate }\end{array}$ & S.E. & $\begin{array}{l}\text { Parameter } \\
\text { estimate }\end{array}$ & S.E. & $\begin{array}{c}\text { Parameter } \\
\text { estimate }\end{array}$ & S.E. \\
\hline Intercept & -0.738 & $(0.178)$ & -0.807 & (0.196) & -1.581 & $(0.241)$ & -2.253 & $(0.288)$ \\
\hline Existing Information & -0.409 & (0.434) & -0.475 & $(0.443)$ & -0.226 & $(0.466)$ & -0.116 & (0.492) \\
\hline New Information & $-0.525^{*}$ & $(0.237)$ & $-0.576^{*}$ & $(0.243)$ & $-0.552^{*}$ & $(0.255)$ & $-0.628^{*}$ & $(0.279)$ \\
\hline Testing & $-0.722^{*}$ & $(0.357)$ & $-0.672 * *$ & $(0.362)$ & -0.370 & $(0.381)$ & -0.440 & (0.423) \\
\hline Technical Standards & $-0.817^{*}$ & $(0.239)$ & $-0.794^{*}$ & $(0.246)$ & $-0.746^{*}$ & $(0.263)$ & $-0.696^{*}$ & $(0.289)$ \\
\hline Financial & -0.501 & $(0.401)$ & -0.648 & $(0.420)$ & -0.528 & $(0.436)$ & $-0.760^{* *}$ & $(0.451)$ \\
\hline Enforcement & $-0.773^{*}$ & (0.271) & $-0.712^{*}$ & $(0.278)$ & $-0.720^{*}$ & (0.299) & $-1.080^{*}$ & (0.335) \\
\hline Closure & $0.820^{*}$ & $(0.309)$ & $0.908^{*}$ & $(0.315)$ & $1.001^{*}$ & $(0.335)$ & $0.854^{*}$ & (0.361) \\
\hline Corrective Action & -0.490 & $(0.810)$ & -0.724 & $(0.834)$ & -0.517 & $(0.841)$ & -0.869 & (0.861) \\
\hline Containers & & & -0.314 & $(0.589)$ & -0.118 & $(0.649)$ & 0.370 & $(0.709)$ \\
\hline Tanks & & & 0.370 & $(0.272)$ & $0.951^{*}$ & $(0.305)$ & $0.900^{*}$ & $(0.350)$ \\
\hline Piles & & & -0.405 & $(0.679)$ & -0.445 & $(0.727)$ & -0.594 & (0.782) \\
\hline Impoundments & & & 0.117 & $(0.551)$ & -0.067 & $(0.602)$ & -0.215 & (0.647) \\
\hline Incinerators & & & -0.527 & $(0.780)$ & -0.158 & (0.786) & -0.374 & (0.808) \\
\hline Landfills & & & 0.543 & $(0.496)$ & 0.157 & (0.572) & -0.301 & (0.628) \\
\hline Land Treatment & & & $-1.822 * *$ & (1.049) & $-2.236^{*}$ & (1.103) & $-2.290^{*}$ & (1.154) \\
\hline Generators & & & $0.670^{* *}$ & $(0.382)$ & $0.832^{*}$ & $(0.408)$ & $0.814^{* *}$ & $(0.466)$ \\
\hline Deadline & & & & & 0.199 & $(0.321)$ & 0.206 & (0.374) \\
\hline Hammer & & & & & $1.633^{*}$ & $(0.277)$ & $1.131^{*}$ & (0.358) \\
\hline Court Deadline & & & & & $0.957^{*}$ & $(0.384)$ & -0.182 & $(0.450)$ \\
\hline Court Remand & & & & & $0.744^{*}$ & $(0.256)$ & 0.078 & $(0.296)$ \\
\hline Total Versions & & & & & & & 0.037 & $(0.029)$ \\
\hline Major Rule & & & & & & & $0.823^{*}$ & (0.293) \\
\hline OSWERs & & & & & & & $1.924^{*}$ & (0.259) \\
\hline Log likelihood & \multicolumn{2}{|c|}{-347.8} & \multicolumn{2}{|c|}{-341.6} & \multicolumn{2}{|c|}{-314.9} & \multicolumn{2}{|c|}{-274.2} \\
\hline $\begin{array}{l}\text { Number of } \\
\text { Observations }\end{array}$ & \multicolumn{2}{|l|}{697} & \multicolumn{2}{|l|}{697} & \multicolumn{2}{|l|}{697} & \multicolumn{2}{|c|}{697} \\
\hline
\end{tabular}

* = statistically significant at $5 \%$ level; ** = statistically significant at the $10 \%$ level.

Note: Sample consists of formal rules implementing RCRA. Dependent variable in logit equals 1 if there is at least 1

Hotline response covering the formal rule. 


\section{TABLE 11}

Determinants of Court Remands: Logistic Regressions Predicting Whether the Rule Was the Subject of a Court Remand

(1)

\begin{tabular}{|c|c|c|c|c|c|c|c|c|}
\hline & & & & \\
\hline & $\begin{array}{l}\text { Parameter } \\
\text { estimate }\end{array}$ & S.E. & $\begin{array}{c}\text { Parameter } \\
\text { estimate }\end{array}$ & S.E. & $\begin{array}{c}\text { Parameter } \\
\text { estimate }\end{array}$ & S.E. & $\begin{array}{l}\text { Parameter } \\
\text { estimate }\end{array}$ & S.E. \\
\hline Intercept & -1.695 & $(0.202)$ & -1.423 & $(0.214)$ & -1.438 & $(0.228)$ & -2.151 & $(0.276)$ \\
\hline Existing Information & 0.454 & $(0.432)$ & 0.399 & $(0.437)$ & 0.391 & $(0.440)$ & 0.364 & $(0.496)$ \\
\hline New Information & 0.318 & $(0.226)$ & 0.250 & (0.234) & 0.235 & (0.235) & 0.308 & $(0.253)$ \\
\hline Testing & $-0.775^{* *}$ & $(0.468)$ & $-0.893^{* *}$ & $(0.476)$ & $-0.979 *$ & $(0.479)$ & $-0.964 *$ & $(0.497)$ \\
\hline Technical Standards & $-0.693^{*}$ & $(0.278)$ & $-0.703^{*}$ & $(0.289)$ & $-0.743^{*}$ & $(0.290)$ & $-0.586 * *$ & $(0.313)$ \\
\hline Financial & -0.071 & $(0.403)$ & 0.334 & $(0.473)$ & 0.409 & $(0.481)$ & 0.065 & $(0.550)$ \\
\hline Enforcement & $1.226^{*}$ & $(0.235)$ & $1.101^{*}$ & (0.244) & $1.170^{*}$ & $(0.249)$ & $0.980^{*}$ & (0.273) \\
\hline Closure & $1.857^{*}$ & $(0.312)$ & $1.932^{*}$ & $(0.336)$ & $1.893^{*}$ & $(0.341)$ & $1.611^{*}$ & (0.374) \\
\hline Containers & & & -0.562 & $(0.792)$ & -0.483 & (0.798) & -0.047 & $(0.797)$ \\
\hline Tanks & & & $-1.936^{*}$ & $(0.457)$ & $-2.135^{*}$ & $(0.467)$ & $-1.720^{*}$ & $(0.512)$ \\
\hline Piles & & & -1.514 & (1.090) & -1.453 & (1.094) & -1.515 & (1.157) \\
\hline Impoundments & & & -0.841 & $(0.804)$ & -0.783 & $(0.807)$ & -0.855 & $(0.890)$ \\
\hline Incinerators & & & 0.887 & $(0.563)$ & 0.915 & (0.569) & 0.560 & $(0.644)$ \\
\hline Landfills & & & -0.874 & $(0.803)$ & -0.789 & (0.809) & -1.094 & $(0.866)$ \\
\hline Land Treatment & & & -0.287 & (0.613) & -0.232 & $(0.620)$ & -0.232 & $(0.722)$ \\
\hline Generators & & & 0.180 & $(0.425)$ & 0.259 & $(0.428)$ & 0.232 & $(0.453)$ \\
\hline Deadline & & & & & $0.916^{*}$ & (0.367) & 0.556 & $(0.415)$ \\
\hline Hammer & & & & & $-0.571^{* *}$ & (0.334) & $-0.779^{*}$ & $(0.430)$ \\
\hline Total Versions & & & & & & & $0.089^{*}$ & $(0.040)$ \\
\hline Major Rule & & & & & & & $-0.713^{*}$ & $(0.327)$ \\
\hline OSWERs & & & & & & & $1.783^{*}$ & $(0.243)$ \\
\hline Log likelihood & -31 & & -30 & & -29 & & -26 & \\
\hline $\begin{array}{l}\text { Number of } \\
\text { Observations }\end{array}$ & 69 & & 69 & & 69 & & 65 & \\
\hline
\end{tabular}

$*$ = statistically significant at $5 \%$ level; $* *=$ statistically significant at the $10 \%$ level.

Note: Sample consists of formal rules implementing RCRA. Dependent variable in logit equals 1 if the courts remanded the rule to the agency or the version of the rule arose from cour actions (including consent decrees). Standard errors are in parentheses. 